Türk Turizm Araştırmaları Dergisi
2021, 5(1): 379-406.
ISOI: $10.26677 /$ TR1010.2021.670

\title{
Örgütsel Destek Algısının Hizmet Kalitesine Etkisinde Personel Güçlendirmenin Aracılık Rolü: Konaklama İşletmeleri Üzerine Bir Araştırma*
}

Dr. Öğr. Üyesi, Aysen ERCAN İ̧̧TiN, Şırnak Üniversitesi, Turizm ve Otel İşletmeciliği Yüksekokulu, Şırnak, e-posta: aysen_ercanistin@sirnak.edu.tr

ORCID: https://orcid.org/0000-0002-7622-361X

Prof. Dr. Bahar TANER, Mersin Üniversitesi, Turizm Fakültesi, Mersin, e-posta: bahartaner@mersin.edu.tr

ORCID: https://orcid.org/0000-0002-4169-6716

Öz

Araştırmada algılanan örgütsel desteğin hizmet kalitesine etkisinde personel güçlendirmenin aracılık rolünün belirlenmesi amaçlanmıştır. Alt amaçları ise örgütsel destek algısının hizmet kalitesi üzerindeki etkisini, personel güçlendirmenin hizmet kalitesi üzerindeki etkisini ve örgütsel destek algısının personel güçlendirme üzerindeki etkisini belirlemektir. Araştırmanın evrenini, 2018 yılında Antalya'daki 5 yıldızlı konaklama işletmelerindeki çalışanlar oluşturmaktadır. Araştırmanın örneklemini, evreni temsil edecek sayıda ulaşılan çalışanlar oluşturmaktadır. Nicel açıdan betimsel araştırma modelinden faydalanılan araştırmada, kolayda örnekleme yöntemi ile Şubat-Nisan 2018 tarihleri arasında toplanan 447 anket verisi analiz edilmiştir. İlgili verilerin analizi sonucunda, algılanan örgütsel desteğin hizmet kalitesine etkisinde personel güçlendirmenin kısmi aracılık etkisi olduğu belirlenmiştir. Araştırmanın alt amaçlarına ilişkin analizler sonucunda, örgütsel desteğin ve personel güçlendirmenin hizmet kalitesi üzerinde etkisi olduğu; örgütsel destek algısının personel güçlendirme algisı üzerinde etkisi olduğu tespit edilmiştir.

* Doktora Tezinden Türetilmiştir (İştin Ercan, A. (2018). Örgütsel Destek Algısının Hizmet Kalitesine Etkisinde Personel Güçlendirmenin Aracılık Rolü: Konaklama İşletmeleri Üzerine Bir Araştırma. Mersin Üniversitesi Sosyal Bilimler Enstitüsü, Turizm İşletmeciliği Anabilim Dalı, Doktora Tezi, Mersin.

Anahtar Kelimeler: Örgütsel Destek, Hizmet Kalitesi, Personel Güçlendirme, Konaklama İşletmeleri, Antalya.

Makale Gönderme Tarihi: 13.11 .2020

Makale Kabul Tarihi: 07.03.2021

\section{Önerilen Atıf:}

Ercan İştin, A. ve Taner, B. (2021). Örgütsel Destek Algısının Hizmet Kalitesine Etkisinde Personel Güçlendirmenin Aracılık Rolü: Konaklama İşletmeleri Üzerine Bir Araştırma, Türk Turizm Araştırmaları Dergisi, 5(1): 379-406.

(c) 2021 Türk Turizm Araştırmaları Dergisi. 


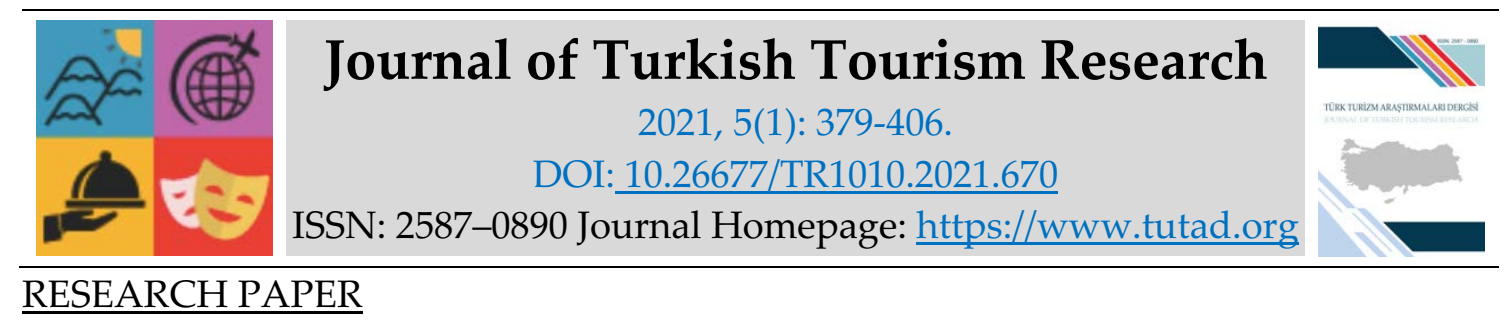

\title{
The Mediating Role of Empowering Personnel in the Effect of Organizational Support Perception on Service Quality: A Study on Hospitality Businesses
}

Assistant Prof. Dr. Aysen ERCAN İŞTiN, Şırnak University, School of Tourism and Hotel Management, Şırnak, e-mail: aysen ercanistin@sirnak.edu.tr

ORCID: https://orcid.org/0000-0002-7622-361X

Prof. Dr. Bahar TANER, Mersin University, Faculty of Tourism, Mersin, e-mail: bahartaner@mersin.edu.tr

ORCID: https://orcid.org/0000-0002-4169-6716

\begin{abstract}
In the research, it was aimed to determine the mediating effect of personnal empowerment in the relationship between organizational support perception and service quality; and secondary objectives are to determine the effect of perceived organizational support on service quality, the effect of personnel empowerment on service quality and the effect of perceived organizational support on personnel empowerment.The research universe consists of the employees who work in 5-star hospitality enterprises of Antalya in 2018. The sample of the research is the employees whose number is representative of the universe. In the research that utilized the descriptive research model in terms of quantitative, the data of 447 questionnaires collected between February and April 2018 by being used simple sampling method were analyzed. As a result of the research, it was determined that a partial mediation effect of the personnel empowerment exists in the relationship between the perceived organizational support and service quality.As a result of the analysis regarding the secondary objectives of the research, it was found that both perceived organizational support and personnel empowerment affect service quality and perceived organizational support affects empowerment.
\end{abstract}

Keywords: Organizational Support, Service Quality, Personnal Empowerment, Hospitality Enterprises, Antalya.

Received: 13.11 .2020

Accepted: 07.03.2021

\section{Suggested Citation:}

Ercan İştin, A. and Taner, B. (2021). The Mediating Role of Empowering Personnel in the Effect of Organizational Support Perception on Service Quality: A Study on Hospitality Businesses, Journal of Turkish Tourism Research, 5(1): 379-406.

(c) 2021 Türk Turizm Araştırmaları Dergisi. 


\section{Gíriş}

Konaklama endüstrisinde çalışmanın bazı kaçınılmaz zorlukları vardır. Bu zorlukların en önemlileri; hafta sonlarında ve bazı resmi tatillerde çalışmak, uzun süreli ve vardiyalı çalışmak, yönetimin adil olmayan ücret politikası ve yöneticilerin çalışanların iş hayatlarını etkileyen diğer konuları görmezden gelmesi ve çalışanlardan işlerine adanmış olmalarını ve boş zamanlarını feda etmelerini beklemeleridir. Ancak yöneticiler, çalışanların motivasyonlarının birbirinden tamamen farklı olduğunu, birçok çalışanın çeşitli nedenlerden dolayı işe daha az yöneldiğini fark edememektedir (Ivanovic ve Blazevic, 2009: 107-109). Bu durum nedeniyle, konaklama işletmeleri yöneticilerinin çalışanlardan yüksek performans, verimlilik elde etmek üzere onların motivasyonlarını arttırabilmek için çalışanları güçlendirici ve destekleyici yollar ve araçlar bulmaları gerekmektedir. Bu noktada modern yönetim uygulamaları içerisinde önemi artan örgütsel destek ve personel güçlendirme ilgi görmekte ve birçok örgüt artık işgörenlerini güçlendirme ve destekleme gereğinin bilinci ile bir takım çalışmalar yapmaktadır. İşgörenlerde örgütsel destek algısının oluşması ve kendi işlerinde kontrol sahibi olmaları, yöneticilerinin onayına gerek kalmadan inisiyatif kullanarak hareket etmeleri, onlarda güven duygusunun artmasını sağlayarak verdikleri hizmet kalitesini arttırabilecektir. Bu nedenlerle konaklama işletmelerinin örgütsel destek ve personel güçlendirmeye yönelik uygulamaları benimsemeleri önem taşımaktadır.

Konaklama endüstrisinde hizmet kalitesini arttırmada örgütsel desteğin ve personel güçlendirmenin önemi yadsınamaz bir gerçektir. Personel güçlendirme önemli davranışsal sonuçlara yol açmaktadır. Örneğin, güçlendirme; çalışanların öz yeterliliğini arttırmakta, çalışanların işlerine daha çok adapte olmasını sağlayarak en yüksek hizmet kalitesi standartlarını yakalamalarını sağlamakta, çalışanları müşteri istek ve ihtiyaçlarını daha hızlı gidermeleri hususunda isteklendirmektedir (Grönroos, 2001:347-348; Chow vd., 2006:283). Örgütsel destek ise, çalışanların görevlerini yerine getirmelerine, işlerini verimli bir şekilde yapmalarına ve stresle baş etmelerine yardımcı olan bir kavramdır. Örgütsel destek, çalışanların örgütte kalma arzusuyla sonuçlanmakta; çalışanlara bir sorumluluk duygusu aşılamakta ve örgütün hedeflerine ulaşmasına yardım ederek örgütün başarısına katkıda bulunmaktadır (Singh ve Singh, 2010:10-14). Buna göre örgütsel destek ve personel güçlendirme çalışanların iş tatminini ve örgüte bağlllıklarını önemli düzeyde etkilediği için onları örgüte bağlayan önemli faktörler olabilir. İyi bir örgüt desteği ve personel güçlendirme uygulamaları ile çalışanların uzun süreli olarak örgüte bağl1lı̆̆ı sağlanabilir.

Konaklama işletmelerinde önemli başarılar çoğunlukla örgüt içerisinde desteklenen ve güçlendirilen işgörenler ile gerçekleşebilmektedir. Böylece, hizmet kalitesinde yükselme ve süreklilik sağlanabilir. Araştırma, işgörenlerin desteklenmelerinin ve güçlendirilmelerinin işletme açısından olumlu etkilerini belirlemek, işletme yöneticilerine hizmet kalitesini artırmaya ilişkin yol göstermek açısından önemlidir. Ayrıca, ulusal ve uluslararası literatürde örgütsel destek, hizmet kalitesi ve personel güçlendirme değişkenleri arasındaki ilişkinin belirlenmesine yönelik olarak yapılmış çalışma sayısının sınırlı olması, araştırma kapsamında elde edilen sonuçların, işletmecilere ve sektöre sağlayacağı katkılarının olması çalışmayı önemli kılmaktadır.

\section{HİZMET KALİTESİ}

1960 yılında Amerikan Pazarlama Derneğinin yapmış olduğu tanıma göre hizmet; malların satışı ile bağlantılı olarak sağlanan faaliyetler, faydalar ya da memnuniyetlerdir (Regan, 1963:57). Performansın beklentileri karşılama derecesi olan kalite ise mal ve hizmetlerde tüketicileri tatmin etmeye yönelik mükemmeliği ifade etmektedir (Chandrupatla, 2009:1-2). 
Hizmet kalitesini ilk tanımlayan Levitt'e (1972) göre, "hizmet kalitesi, hizmet sonuçlarının belirlenmiş standartları karşılayabilmesi durumunu" ifade etmektedir. Grönroos'a (1988) göre, "hizmet kalitesi genel olarak örgüt tarafından verilen hizmet kalitesi ile çalışanların beklediğgi hizmet performansı arasında bir farklılıktır". Kavramsal olarak hizmet kalitesi, hizmetin genel mükemmellik ya da üstünlüğüne ilişkin küresel yargı ya da tutumdur (Munhurrun, Naidoo ve Bhiwajee, 2010:48). Grönroos (2001), birçok hizmetin karmaşık özelliğinden dolayı, malların kalitesine kıyasla hizmet kalitesinin de karmaşık olması gerektiğini savunmaktadır. Mallar söz konusu olduğunda, sürecin nihai sonucu tüketiciye aktarılırken, yüksek teknolojiden yüksek temasa ayrı ayrı hizmetlerden kesintisiz hizmetlere kadar geniş bir yelpazede yer alan hizmetlerde, hizmet çalışanlarının görevlerini yerine getirme şekilleri, söyledikleri ve ayrıca yaptıkları, tüketicilerin hizmete bakışını ve deneyimlerini etkilemektedir (Grönroos, 2001:61). Parasuraman, Zeithaml ve Berry (1988:20-23), hizmet kalitesini somutluk, güvenirlik, sorumluluk, güvence ve empati olmak üzere beş boyutta ele almıştır. Somutluk fiziksel tesisleri, ekipman ve personelin görünümünü; güvenirlik ise hizmeti güvenilir ve doğru bir şekilde gerçekleştirmeyi; sorumluluk tüketiciye yardım etme isteğini ve hızlı hizmet sunmayı; güvence işgörenlerin tecrübe ve nezaketini, kendine güven ve inanmak için ilham verme becerilerini; empati ise firmanın tüketicilerine sunduğu kişiye özel dikkat ve yardımseverliği içermektedir.

Yüksek düzeyde rekabetçi olan konaklama endüstrisinde konaklama işletmelerinin hizmetlerini rakiplerinden farklılaştırmak çok önemlidir. Bunu başarmak için yöneticiler müşterilerinin istek ve ihtiyaçlarını anlayarak kaliteli hizmet sunmalıdır. Böylece pazar payı ve genel karlılık artacaktır. Hizmet kalitesi, turizm ve konaklama endüstrisinde iş uygulamalarının önemli bir parçası haline geldiğinden, konaklama işletmelerinin hizmetlerinin kalitesini net bir şekilde tanımlaması ve psikometrik olarak güvenilir bir ölçüm aracı geliştirmesi gereklidir (Wu ve Ko, 2013: 219). Konaklama endüstrisinde hizmet kalitesi, rekabetçi bir pazarda sürdürülebilir bir rekabet üstünlüğü ve müşteri güvenini kazanmak için önemli faktörlerden biri haline gelmektedir. Ayrıca, hizmet kalitesi, konaklama endüstrisindeki işletmelere rekabetçi bir farklılaşma yaratmak için büyük bir şans sağlayabilir. Bu nedenle, hizmet kalitesi, konaklama endüstrisinde önemli bir temel kavram ve bir başarı faktörü olarak görülmektedir. Başarılı bir konaklama işletmesi müşterilere, mükemmel kalitede hizmet sunduğunda, hizmet kalitesi, konaklama işletmesinin yaşam kaynă̆ 1 olarak kabul edilmektedir. Müşteri sadakati oluşturulması, iş imajına katkıda bulunulması, müşteri memnuniyeti sağlanması gibi pek çok avantaj elde edilmesinin yolu, hizmet kalitesini iyileştirmeden geçmektedir (Al-Ababneh, 2017:1).

\section{ALGILANAN ÖRGÜTSEL DESTEK}

İlk olarak 1986 yılında Eisenberger ve dĭ̆. (1986) örgütsel desteğin tanımını, çalışanların, örgüt tarafından önemsendiklerine, örgüt için sağladıkları katkıya değer verildiğine ve desteklendiğine dair duydukları güven, inanç ve mutluluk durumu olarak ifade etmiştir (Eisenberger vd., 1986:501). Diğer bir tanıma göre algılanan örgütsel destek, çalışanların örgüt tarafından katkılarına değer verildiğine ve onların iyiliğinin ya da refahının önemsendiğine ilişkin genel inançları olarak tanımlanmaktadır (Kraimer ve Wayne, 2004:210). Algılanan örgütsel destek; örgütsel ödüller ve olumlu iş koşulları, adalet ve yönetici desteği gibi çalışanlara yönelik pozitif uygulamalarla ilişkilidir. Bunun karşılığında iş tatmini ve örgütsel bağlllık gibi olumlu sonuçlar elde edilmektedir. Bütün bu ilişkiler örgütsel destek teorisini desteklemektedir (Shumaila vd., 2012:3). Örgütsel destek teorisine göre, çalışanlar örgüt tarafından çeşitli politika, uygulama ve davranışlar yoluyla kendi refahları ile ne kadar ilgilenildiğinin ve desteklendiklerinin farkında olmaktadır. Çalışanlar bu desteğe, artan sadakat ve performansla karşlık vermektedir (Kraimer ve Wayne, 2004:210). Örgütsel desteği etkileyen faktörlerin başında örgütsel adalet, yönetici 
desteği, lider - üye etkileşimi, ödüller ve iş koşulları, kişisel özellikler gelmektedir. Örgütsel adalet, çalışanların iş yerlerinde adil bir şekilde muamele görüp görmediklerine ilişkin tespitleri ve bu tespitlerin işle ilgili diğer değişkenleri etkileme durumudur (Moorman, 1991:845). Lider üye etkileşimi, daha yüksek performansa, yüksek iş tatminine daha güçlü örgütsel bağllllğa ve işgücü devir hızının düşürülmesi gibi çok sayıda olumlu örgütsel çıktıya zemin hazırlamaktadır (Gerstner ve Day, 1997: 828-829). Guchait ve arkadaşlarına (2014) göre yönetici desteği, üyelerin herbiri için bireysel koçluk yapmayı, astların işlerine ilişkin sorumluluklarını yerine getirmeleri husununda desteği ve performans değerlendirmeyi içermektedir (Zincirkıran vd., 2016:977). Çalışan performansında önemli rolü olan ödüller; çalışanların performansını kontrol ederek onları motive etmektedir (Seng ve Arumugam, 2017:52). İşletmelerin kişisel özelliklerle çalışanların verimliliğini ve etkinliğini artırmaya yönelik aldığı tedbirler başarıyı belirleyen unsurlardır (Saltürk, 2008:100).

\section{PERSONEL GÜÇLENDİRME}

Güçlendirme, bireysel ve toplumsal kontrolü, siyasi etkinliği, toplumsal yaşamın kalitesini ve sosyal adaleti arttırma hedeflerine yönelik insanların, organizasyonların ve toplumların katılımını teşvik eden sosyal bir süreçtir (Lord ve Hutchison, 1993:8). Güçlendirme, insanların hayatlarını ve yaşadıkları toplumları etkileyen kurumlar ve örgütler üzerinde etki sahibi olmak için harekete geçmelerini sağlayan, ayrıca insanların kişisel ve sosyal değişim yaşadığı interaktif bir süreç olarak tanımlanmaktadır (Whitmore, 1990:216). Güçlendirme kavramı davranışsal (yapısal) ve psikolojik (bilişsel) yaklaşımlar olmak üzere iki boyutla açıklanmaktadır. Davranışsal güçlendirme, teorik olarak bir organizasyonun çalışma ortamında çalışanlara bilgi, kaynak, destek ve fırsattan yararlanma imkanı sağlama becerisi olarak tanımlanmaktadır (O'Brien, 2010:6). Kanter (1993)'in davranışsal güçlendirme teorisine göre çalışanlar; öğrenme ve gelişme fırsatlarına, desteğe, kaynaklara ve bilgiye erişebilmeleri sağlanarak iş çevresinde desteklenmektedir (Larkin vd., 2008:1). Kanter (1993)'e göre gü̧̈, işleri gerçekleştirmek için kaynakları harekete geçirme yeteneğidir. Çalışanlar; öğrenme ve gelişme fırsatlarına, kaynaklara, destek ve bilgi hatlarına erişebildiklerinde güç açıktır. Bu hatlar kullanılmadığında, güç kapalıdır ve etkili çalışma mümkün değildir. Bu güç hatları, organizasyon içinde davranışsal güçlendirmenin kaynaklarıdır; örgütlerdeki resmi ve gayri resmi sistemlerden doğmaktadır. Resmi güç; esneklik, uyarlanabilirlik, isteğe bağlı karar verme ile ilişkili yaratıcılık, görünürlük ve örgütsel hedeflere odaklanma gibi belirli iş özelliklerinden türetilmektedir. Gayri resmi güç; sosyal bağlantılardan, gelişmiş iletişimden, bilgi kanallarından, astlardan ve çapraz fonksiyonel gruplardan türetilmektedir. Yüksek davranışsal güçlendirme, bu yapılara erişimden kaynaklanmaktadır (Ramos ve Ales, 2014:29). Psikolojik güçlendirme, teorik olarak bireyin kendi çevresi üzerinde kontrol sahibi olduğu ve kendi değerleri ile organizasyonun değerleri arasında bir uyuşma hissinde olduğu algısı olarak tanımlanmaktadır (O'Brien, 2010:6). Psikolojik güçlendirme; yeterlilik, özerklik, iş anlamlılığı ve örgüte etki etme becerisi duygularını içermektedir. Güçlendirilen çalışanlar; örgüte daha bağlıdır; işine karşı daha fazla sorumludur ve iş taleplerini etkili bir şekilde yerine getirme imkanı bulmaktadır (Larkin vd., 2008:1). Spreitzer (1995), Thomas ve Velthouse' in (1990) çalışmasından esinlenerek psikolojik güçlendirme terimini kullanmış ve güçlendirmeyi; dört boyutta incelemiştir: anlam (meaning), yeterlik (competence), özerklik (self-determination) ve etki (impact). Anlam boyutu, kişinin işine ilişkin üstlendiği rol ile değerlerinin, amaçlarının ve davranışlarının uyumunu ifade ederken; yeterlilik boyutu, kişinin işinin gerekliliklerini tamamlamak için kendi gücüne / yeteneğine ve ustalığına / uzmanlığına olan inancını ifade eder. Özerklik boyutu ise, kişinin işinde kendi başına inisiyatif kullanabilmesini ya da iş yapma şeklini ve yöntemini kendinin belirleyebilmesini, işiyle ilgili tek 
başına karar verebilmesini ifade ederken; etki boyutu, kişinin işinin örgütsel çıktıları etkileyebilme gücünü ifade etmektedir (Spreitzer, 1995:1443-1444).

Güçlendirme, hizmet kalitesi ve müşteri memnuniyetinin önemli bir belirleyicisidir. Güçlendirilmiş çalışanlar, müşterilerin ihtiyaçlarını karşılamak ve sorunlarını çözmek için kendi yetkilerini kullanmaktadır. Böylece hizmet kalitesi ve müşteri memnuniyeti artmaktadır. Güçlendirme, önemli davranışsal sonuçlara yol açmaktadır. Örneğin güçlendirme, müşterilere hizmet vermenin en iyi yolunu çalışanların belirlemesine izin verdiği için onların özyeterliliklerini güçlendirmektedir. Ayrıca güçlendirme, çalışanların işe daha çok adapte olmalarına öncülük etmektedir. Güçlendirmeyle çalışanlar müşteri taleplerini karşılayabilmekte ve en yüksek hizmet kalitesi standartlarını sağlayabilmektedir. Güçlendirme için çalışanların hizmet kalitesini yükseltmede inisiyatif alarak başarılı olmaları bir ön şarttır. Böylece müşteri ihtiyaçları daha hızlı giderilebilir ve daha verimli bir şekilde çözülebilir. Çalışanlar, müşterilerin hizmet sorunlarını çözmek için güçlendirilirse ve onlara güvenilirse, daha kaliteli hizmet sunar ve işlerinden gurur duyarlar (Chow vd., 2006:483).

\section{DEĞİŞKENLER ARASINDAKİ İLİ̧̧KILER}

Örgütsel destek algisı ve hizmet kalitesi ilişkisi konusunda yapılan çeşitli araştırmalar bulunmaktadır. Garg ve Dhar (2014) Hindistan'da faaliyet gösteren 36 küçük ve orta ölçekli oteldeki işgörenler üzerine yapmış oldukları araştırmada bağlılık düzeyini etkileyen ve hizmet kalitesini etkileyen faktörleri incelemişlerdir. Buna göre örgütsel bağlılığın; iş stresi, lider üye değişimi ve örgütsel destek ile hizmet kalitesi arasında aracılık rolü olduğu tespit edilmiştir. Özbek ve Kosa (2010) örgütsel destek, üst yönetim desteği, duygusal bağlllık ve personel güçlendirmenin hizmet kalitesi ile olan ilişkisini inceledikleri araştırmalarında örgütsel destek ile hizmet kalitesi arasında doğrusal ve pozitif yönlü bir ilişki olduğunu tespit etmişlerdir. Araştırmanın bu bağlamda geliştirilen hipotezi $\left(\mathrm{H}_{1}\right)$;

$\mathrm{H}_{1}$ : Örgütsel destek algısının hizmet kalitesi üzerinde olumlu yönde anlamlı bir etkisi vardır.

Baumgartner (2014)'ın, ağırlama endüstrisi için güçlendirmenin önemini vurgulamak amacıyla Viyana'daki Ritz-Carlton otelinde yaptı̆̆ı araştırmada; personel güçlendirme, hizmet kalitesi ve iş doyumu arasındaki ilişki incelenmiştir. Araştırma sonucunda, güçlendirmenin hizmet kalitesi üzerinde pozitif bir etkiye sahip olduğu bulgulanmıştır. Dimitriades ve Maroudas (2007:391) ile Samat vd., (2006:723) yaptıkları araştırmalarında da personel güçlendirme ile hizmet kalitesi arasında anlamlı ve pozitif yönlü bir ilişkinin varlığını tespit etmişlerdir. İşgörenlerin yaptıkları işlere yönelik kontrol sahibi olmaları onlarda kendilerine güven duygusunun gelişmesini sağlayarak verdikleri hizmetin kalitesinin artmasında olumlu etki yapabilir. Özbek ve Kosa (2010) örgütsel destek, üst yönetim desteği, duygusal bağlllık ve personel güçlendirmenin hizmet kalitesi ile olan ilişkisini inceledikleri araştırmalarında personel güçlendirme ile hizmet kalitesi arasında doğrusal ve pozitif yönlü bir ilişki olduğunu tespit etmişlerdir. Araştırmanın bu bağlamda geliştirilen hipotezi $\left(\mathrm{H}_{2}\right)$;

$\mathrm{H}_{2}$ : Personel güçlendirme algısının hizmet kalitesi üzerinde olumlu yönde anlamlı bir etkisi vardir.

Chow ve arkadaşları (2006) araştırmalarında, insan kaynakları yönetiminin seçilmiş üç yönü, yani gelişimsel deneyime erişim, örgütsel destek, güçlendirme ve bunların müşteri yönelimi ve performans sonuçlarına etkisi üzerine odaklanmıştır. Gerekçeler, işgörenlere gelişimsel deneyim yoluyla becerilerini geliştirmeleri, onları güçlendirme ve kaliteli hizmet sunmak için gerekli desteği sağlamaya fırsatlar sunmaktır. Araştırmanın sonucunda hem örgütsel desteğin hem de personel güçlendirmenin müşteri yönelimi üzerinde güçlü bir etkiye sahip olduğu belirlenmiştir. 
Ancak gelişimsel deneyimin, yalnızca performans üzerinde belirgin bir etkiye sahip olduğu görülmüştür. Karavardar (2014) araştırmasında psikolojik güçlendirme, algılanan örgütsel destek, örgütsel vatandaşlık davranışı, işe gömülme ve iş performansı arasındaki ilişkiyi incelemiştir. Araştırma sonucuna göre psikolojik güçlendirme, algılanan örgütsel destek, örgütsel vatandaşlık davranışı, işe gömülme ve iş performansı arasında güçlü bir ilişki olduğu görülmüştür. Araştırmanın bu bağlamda geliştirilen hipotezi:

$\mathrm{H}_{3}$ : Örgütsel destek algısının personel güçlendirme algısı üzerinde olumlu yönde anlamlı bir etkisi vardır.

Neden-sonuç ilişkisi içinde olan değişkenlerde neden durumunda olan değişkene bağımsız değişken, sonuç durumunda olan değişkene ise bağımlı değişken denilmektedir. Bir değişken aşağıdaki şartları yerine getirdiğinde ise mediatör değişken olarak ele alınır (Baron ve Kenny, 1986:1176-1177):

1. Bağımsız değişkenin düzeyindeki değişimler, tahmin edilen mediatör değişkenindeki değişimlerin nedenini anlamlı bir şekilde açıladığında (Şekil 1'de "a" yolu),

2. Mediatör değişkendeki değişimler bağımlı değişkendeki değişimlerin nedenini anlamlı bir şekilde açıkladığında (Şekil 1'de "b" yolu),

3. a ve b yolu kontrol altında tutulduğunda, bağımlı ve bağımsız değişken arasında önceden anlamlı olan ilişkide standardize edilmemiş regresyon katsayılarında azalma olur ise ya da önceden anlamlı olan ilişki anlamlı değil ise (Şekil 1'de "c" yolu).

Bu bağlamda, mediatör değişkene ilişkin belirtilen temel düşünceler çerçevesinde araştırmanın dördüncü hipotezi geliştirilmiş ve Şekil 1'de araştırmanın simgesel modeline yer verilmiştir.

$\mathrm{H}_{4}$ : Örgütsel destek algısının hizmet kalitesine etkisinde personel güçlendirmenin aracılık rolü vardir.

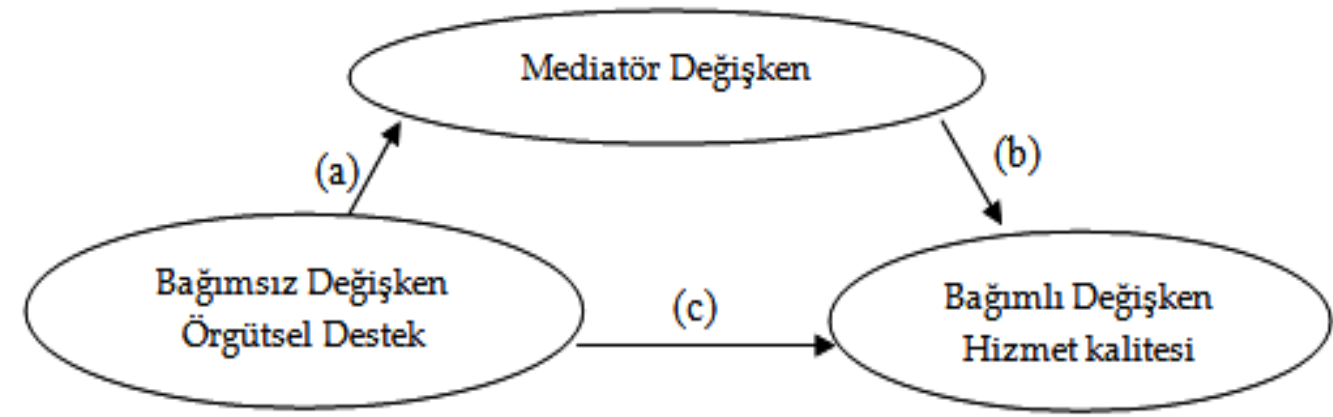

Şekil 1. Araştırmanın Simgesel Modeli

\section{YÖNTEM}

Araştırmada, örgütsel destek algısının hizmet kalitesine etkisi araştırılıp bu etkide personel güçlendirmenin aracılık rolünün belirlenmesi amaçlanmıştır. Bu kapsamda çalışma, araştırma modeli açısından bir tarama niteliğindedir.Çalışmanın evrenini, Antalya'daki beş yıldızlı konaklama işletmelerinde çalışan personeller oluşturmaktadır. Çalışmada, beş yıldızlı konaklama işletmelerinin seçilme nedeni, profesyonelce yönetilmeleri ve kurumsallaşmış olmalarından kaynaklanmaktadır. Araştırmanın örneklemini ise evreni temsil edecek sayıda ulaşılan çalışanlar oluşturmaktadır. Örneklemin belirlenmesi için öncelikle Antalya'daki beş yıldızlı konaklama işletmelerinde çalışanların sayısının tespit edilmeye çalışılmış; ancak çalışan 
sayısı için kesin bir istatistiksel bilgiye ulaşılamamıştır. Bu nedenle, Ertaş ve Unur (2018)'un yapmış oldukları çalışmaya göre beş yıldızlı konaklama işletmelerinde oda başına düşen personel sayısı 0,9 (Ertaş ve Unur, 2018:218) ve oda sayısı ise 95,820 (Antalya İl Kültür Turizm Bakanlığı, 2018) olarak alınıp çalışan sayısı (N=evren büyüklüğ̈̈) hesaplanmıştır. Çalışan sayısı $(0,9 \times 95,820)$ 86,238 olarak belirlenmiştir. Buradan hareketle, çalışma evreninin 10.000'in üzerinde olması nedeniyle iki işgörenden birinin çalışmaya ilgi gösterebileceği $(0,50)$ varsayılarak, \%5 güven düzeyinde ve \%5 örneklem hatası ile örneklem büyüklüğü (Özdamar, 2013: 107), oran için sinırsız evren formülü $\left(\mathrm{n}=\left(\mathrm{PxQxZ \alpha} \alpha^{2}\right) / \mathrm{H}^{2}=0,5^{*} 0,5^{*} 1,96^{2} / 0,05^{2}=384\right)$ kullanılarak 384 kişi olarak tespit edilmiştir (Ural ve Kılıç, 2006: 47).

Antalya'daki 5 yıldızlı otel çalışanlarının fazla olması ve çalışmaya gönüllü katılımcıların örnekleme dahil edilmesi nedeniyle araştırmada kolayda örnekleme yoluna gidilmiştir. Araştırma verileri Şubat-Nisan 2018 tarihleri arasında alan yazına dayalı olarak geliştirilen anket vasıtasıyla çalışanlardan toplanmıştır. Araştırmada, hizmet kalitesini ölçmek için orjinali Parasuraman ve arkadaşlarına (1988) ait olan ancak, Mallhotra ve Mukherjee (2004) tarafından kısaltılmış olan ölçek kullanılmıştır.Araştırmada, personel güçlendirmeye ilişkin veriler, Spreitzer (1995); örgütsel desteği ölçmeye ilişkin veriler ise Eisenberger ve arkadaşlarının (1986) geliştirdiği ölçek temel alınarak toplanmıştır. Orijinal dilleri İngilizce olan anket formlarında, hizmet kalitesi için 11 ifade yer alırken; personel güçlendirme için 12 ifadenin, örgütsel destek içinse 36 ifadenin yer aldığı görülmektedir. Ölçekte yer alan ifadelere katılımcılar, 5'li Likert derecelendirmesini dikkate alarak cevap vermişlerdir. Araştırma öncesinde beş yıldızlı 23 otel ile telefonla ön görüşme yapılmış; araştırmanın amacına ilişkin detaylı bilgi verilerek işletmedeki yöneticilerin izinleri ve görüşlerialınmış; beş yıldızlı otellerden 8 tanesi araştırma dahilinde yer almak istediklerini ifade etmişlerdir. Toplanan verilerin 179 tanesi görüşülen bu otellerden posta yoluyla sağlanmıştır. Otel işletmelerine ilişkin iş ilanları web sitelerinde, iş ilanı veren 307 yetkili kişiye mail adresiyle ulaşılmış; yine araştırmanın amacına ilişkin bilgi verilerek, araştırmada kullanılan anketin çevrimiçi olarak ulaşılabileceği bağlantı adresi eklenip ankete katılımları sağlanmıştır. Böylelikle 120 anket iş ilanları web sitelerinden elektronik posta yoluyla elde edilmiştir. Son olarak beş yıldızlı 19 otel ile yüz yüze görüşülüp ankete katılımları sağlanarak 192 anket elde edilmiştir. Toplanan 491 anketin 32 tanesinin büyük çoğunluğu boş bırakıldığından dolayı veri setine dahil edilmemiştir. 459 anket veri sağlamaya elverişli düzeyde bulunmuştur. Veri setindeki değişkenlerin çok değişkenli istatistiksel analize uygunluğunu tespit etmek amacıyla çoklu normal dağılım testi yapılmıştır. Test sonucunda verilerin normal dağılmadığ görülmüştür. Bu nedenle sapan analizi yapılarak uç değerler tespit edilip 12 anket veri setinden çıkarılarak çoklu normal dağılım sağlanmıştır. Dolayısıyla 447 anket üzerinden analizler gerçekleştirilmiştir.

Çalışmada, hizmet kalitesi ölçeğinin güvenirliği test edilmiş ve bu ölçek için güvenirlik katsayısı olarak Cronbach's Alpha değeri 0,832 olarak tespit edilmiştir. Araştırmada kullanılan algılanan örgütsel destek ölçeğinin güvenirlik analizinde Cronbach's Alpha değeri 0,854 olarak; personel güçlendirme ölçeğinin Cronbach's Alpha değeri ise, 0,889 olarak saptanmıştır. Otel çalışanlarının algılanan örgütsel destek ölçeğinin yapı geçerliliğini test etmek için ölçeğe faktör analizi uygulanmıştır.Otel çalışanlarının algılanan örgütsel destek ölçeğine yapılan faktör analizi, 28 maddelik ölçeği, 5 faktör altında boyutlamıştır. Elde edilen boyutlar; önemseme, göz ardı edilme, gözden çıkarılma, gururlandırma ve maaşla ödüllendirilme ve anlayışla karşılanma olarak adlandırılmıştır. Son aşamada, hizmet kalitesi ölçeğine yapılan faktör analizi, 8 maddelik ifadeyi 2 faktör altında boyutlamıştır. Söz konusu boyutlara, sorumluluk ve empati; güven verme ve özen gösterme isimleri verilmiştir. Personel güçlendirme ölçeğine uygulanan faktör analizi sonucunda ise etki, özerklik ve yeterlilik ve anlam olarak ölçeğin 3 boyut altında yapılandığı tespit edilmiştir. 


\section{BULGULAR}

Araştırmaya katılan 447 otel çalışanının demografik ve mesleki özelliklerine ilişkin bulgular incelendiğinde; cinsiyete göre kadınlar toplam katılımclların \% 47,2' sini ve erkekler ise \% 52,8' ini oluşturmaktadır. Evliler \% 43'ünü bekarlar \% 57'sini oluşturmaktadır. Yaş değişkenine göre çalışanların \% 34'ünün 32-38 yaş arasında olduğu; eğitim durumuna göre ise çalışanların $\% 52,5$ 'inin lisans düzeyinde eğitime sahip oldukları görülmektedir. Çalışılan pozisyona göre katılımcıların \% 67,8'ini yönetici çalışanlar ve \% 32,2'sini ise yönetici olmayan çalışanlar oluşturmaktadır. Kurumdaki çalışma süresine göre; 1-12 ay arası çalışanlar \% 47,7'lik oranla grubun çoğunluğunu oluşturmaktadır.

Araştırma kapsamında geliştirilen birinci hipotez, "Örgütsel destek algısının hizmet kalitesi üzerinde olumlu yönde anlamlı bir etkisi vardır" şeklinde geliştirişlmiştir. Geliştirilen hipotezi test etmek amaciyla basit doğrusal regresyon analizi; analizlerde de enter metodu kullanılmıştır.Örgütsel destek boyutlarının hizmet kalitesi boyutları üzerindeki etkisini belirlemek amacıyla yapılan basit doğrusal regresyon analizinin sonuçları Tablo 1'de yer almaktadir.

Tablo 1'de analiz sonuçlarına göre, algılanan örgütsel destek boyutlarından olan önemsenme, göz ardı edilme, gözden çıkarılma ve gururlandırma boyutlarının hizmet kalitesi boyutları olan sorumluluk ve empati ile güven verme ve özen gösterme boyutları üzerinde anlamlı bir etkisi olduğu saptanmıştır. Öte yandan, maaşla ödüllendirme ve anlayışla karşılama örgütsel destek boyutunun hizmet kalitesi boyutlarından olan güven verme ve özen gösterme boyutu üzerinde anlamlı etkisi söz konusuyken sorumluluk ve empati boyutu üzerinde ise istatistiksel olarak anlamlı bir etkisi olmadığ 1 tespit edilmiştir. Örgütsel destek boyutlarından olan önemsenme boyutunun bağımsız, hizmet kalitesi boyutlarından olan sorumluluk ve empati boyutunun bağımlı değişken olarak alındığı regresyon analizi sonucunda, modelin $(F=24,280, p=, 000)$ istatistiki olarak anlamlı olduğu tespit edilmiştir. R değerinin ,227 olması, değişkenler arasında düşük pozitif yönlü bir ilişki olduğunu göstermektedir. $\mathrm{R}^{2}, 052$ olarak hesaplanmıştır. Bu durumda, çalışanların sorumluluk ve empatiye ilişkin algılarında değişkenliğin \%5,2'sinin bağımsız değişken olan önemsenme ile açıklandığı ifade edilebilir. Önemsenme boyutunun güven verme ve özen gösterme üzerindeki etkisi de $(F=35,508, p=, 000)$ istatistiki olarak anlamlı bulunmuştur. R değerinin ,272 olması, değişkenler arasında düşük pozitif ilişki olduğunu göstermektedir. $\mathrm{R}^{2}, 074$ olarak hesaplanmıştır. Bu durumda, çalışanların güven verme ve özen göstermeye ilişkin algılarındaki değişkenliğin \% 7,4'ünün bağımsız değişken olan önemsenme ile açıklandığı ifade edilebilir. Maaşla ödüllendirme ve anlayışla karşılanma boyutunun sorumluluk ve empati üzerindeki etkisinin $(F=2,360, p=, 125)$ istatistiki olarak anlamlı olmadiğ 1 görülmüştür. Dolayısıyla, maaşla ödüllendirme ve anlayışla karşılanma ile sorumluluk ve empati algısı arasında anlamlı bir ilişkinin bulunmadığı anlaşılmaktadır. Model anlamsız çıktığı için, sonuca dönük basit doğrusal regresyon modeli kurulamamıştır.Öte yandan maaşla ödüllendirme ve anlayışla karşılanma boyutunun güven verme ve özen gösterme üzerindeki etkisi ( $F=10,032$ $\mathrm{p}=, 002)$ istatistiki olarak anlamlı bulunmuştur. R değerinin ,148 olması, değişkenler arasında zayıf pozitif bir ilişki olduğunu göstermektedir. $\mathrm{R}^{2}, 022$ olarak hesaplanmıştır. Bu durumda, çalışanların güven verme ve özen göstermeye ilişkin algılarındaki değişkenliğin \%2,2'sinin bağımsız değişken olan maaşla ödüllendirme ve anlayışla karşılanma ile açıklandığı ifade edilebilir. 
Tablo 1. Algılanan Örgütsel Destek Boyutlarının Hizmet Kalitesi Boyutlarına Etkisi

\begin{tabular}{|c|c|c|c|c|c|c|}
\hline \multirow[t]{2}{*}{$\begin{array}{c}\text { Bağımlı } \\
\text { Değişken }\end{array}$} & \multirow[t]{2}{*}{$\begin{array}{l}\text { Model (Sabit) ve } \\
\text { Bağımsız Değişken }\end{array}$} & \multicolumn{2}{|c|}{$\begin{array}{c}\text { Standardize } \\
\text { Edilmemiş } \\
\text { Katsayılar } \\
\end{array}$} & \multirow{2}{*}{$\begin{array}{c}\begin{array}{c}\text { Standardize } \\
\text { Katsayılar }\end{array} \\
\text { Beta } \\
\end{array}$} & \multirow[t]{2}{*}{ T Değeri } & \multirow{2}{*}{$\begin{array}{l}\text { Anlam } \\
\text { Düzeyi }\end{array}$} \\
\hline & & Beta & Std. Hata & & & \\
\hline \multirow[b]{2}{*}{$\begin{array}{l}\text { Sorumluluk ve } \\
\text { Empati }\end{array}$} & (Sabit) & 3,824 & 109 & & 35,080 & 000 \\
\hline & Önemsenme & 144 & ,029 & 227 & 4,927 & , 000 \\
\hline \multicolumn{7}{|c|}{ R: ,227; R²: ,052; Düzeltilmiş R²: ,050; Model için F: 24,280; $p=$,000; D-W: 1,716 } \\
\hline \multirow{2}{*}{$\begin{array}{l}\text { Güven Verme } \\
\text { ve Özen } \\
\text { Gösterme } \\
\end{array}$} & (Sabit) & 3,635 & 125 & & 29,081 & ,000 \\
\hline & Önemsenme & ,199 & 033 & ,272 & 5,959 & ,000 \\
\hline \multicolumn{7}{|c|}{ R: ,272; R²: ,074; Düzeltilmiş R2: ,072; Model için F: 35,508; p= ,000; D-W: 1,572 } \\
\hline \multirow{2}{*}{$\begin{array}{l}\text { Sorumluluk ve } \\
\text { Empati }\end{array}$} & (Sabit) & 4,098 & 086 & & 47,727 & , 000 \\
\hline & $\begin{array}{l}\text { Göz Ardı Edilme } \\
\text { Durumu }\end{array}$ & ,078 & 026 & ,143 & 3,047 & 002 \\
\hline \multicolumn{7}{|c|}{ R: ,143; R2: ,020; Düzeltilmiş R2: ,018; Model için F: 9,285; $p=$,002; D-W: 1,767 } \\
\hline \multirow{2}{*}{$\begin{array}{l}\text { Güven Verme } \\
\text { ve Özen } \\
\text { Gösterme }\end{array}$} & (Sabit) & 4,047 & ,099 & & 40,704 & ,000 \\
\hline & $\begin{array}{l}\text { Göz Ardı Edilme } \\
\text { Durumu }\end{array}$ & ,098 & , 030 & ,155 & 3,303 & ,001 \\
\hline \multicolumn{7}{|c|}{ R: ,155; R²: ,024; Düzeltilmiş R2: ,022; Model için F: 10,908; $p=$ =,001; D-W: 1,608 } \\
\hline \multirow{2}{*}{$\begin{array}{l}\text { Sorumluluk ve } \\
\text { Empati }\end{array}$} & (Sabit) & 3,956 & ,091 & & 43,388 & , 000 \\
\hline & $\begin{array}{l}\text { Gözden Çıkarılma } \\
\text { Durumu }\end{array}$ & 116 & ,026 & ,206 & 4,451 & , 000 \\
\hline \multicolumn{7}{|c|}{ R: ,206; R2: ,043; Düzeltilmiş R : 040; Model için F: 19,808; $p=$ =,000; D-W: 1,815 } \\
\hline \multirow{2}{*}{$\begin{array}{l}\text { Güven Verme } \\
\text { ve Özen } \\
\text { Gösterme }\end{array}$} & (Sabit) & 3,982 & 106 & & 37,391 & ,000 \\
\hline & $\begin{array}{l}\text { Gözden Çıkarılma } \\
\text { Durumu }\end{array}$ & 113 & , 031 & ,173 & 3,701 & , 000 \\
\hline \multicolumn{7}{|c|}{ R: ,173; R²: ,030; Düzeltilmiş R²: ,028; Model için F: 13,695; $p=$ =,000; D-W: 1,639 } \\
\hline \multirow{2}{*}{$\begin{array}{l}\text { Sorumluluk ve } \\
\text { Empati }\end{array}$} & (Sabit) & 3,779 & 112 & & 33,794 & 000 \\
\hline & Gururlandirma & 157 & 030 & 240 & 5,209 & , 000 \\
\hline \multicolumn{7}{|c|}{ R: ,240; R2: ,057; Düzeltilmiş R2: ,055; Model için F: 27,129; p= ,000; D-W: 1,735 } \\
\hline \multirow{2}{*}{$\begin{array}{l}\text { Güven Verme } \\
\text { ve Özen } \\
\text { Gösterme }\end{array}$} & (Sabit) & 3,722 & 130 & & 28,639 & ,000 \\
\hline & Gururlandirma & , 176 & , 035 & ,232 & 5,035 & , 000 \\
\hline \multicolumn{7}{|c|}{ R: ,232; R²: ,054; Düzeltilmiş R: ,052; Model için F: 25,346; $p=$ =,000; D-W: 1,583 } \\
\hline \multirow{2}{*}{$\begin{array}{l}\text { Sorumluluk ve } \\
\text { Empati }\end{array}$} & (Sabit) & 4,227 & 084 & & 50,486 & ,000 \\
\hline & \begin{tabular}{|l|} 
Maaşla Ödüllendirme \\
ve Anlayışla \\
Karşılanma
\end{tabular} & ,041 & ,027 & ,073 & 1,536 & ,125 \\
\hline \multicolumn{7}{|c|}{ R: ,073; R²: ,005; Düzeltilmiş R²: ,003; Model için F: 2,360; p= ,125; D-W: 1,756 } \\
\hline \multirow{2}{*}{$\begin{array}{l}\text { Güven Verme } \\
\text { ve Özen } \\
\text { Gösterme }\end{array}$} & (Sabit) & 4,070 & 096 & & 42,267 & 000 \\
\hline & \begin{tabular}{|l|} 
Maaşla Ödüllendirme \\
ve Anlayışla \\
Karşılanma
\end{tabular} & ,097 & ,031 & , 148 & 3,167 & ,002 \\
\hline 14 & ; $\mathrm{R}^{2}:$, 022; Düzeltilmiş & 220 . & $\operatorname{in} 5$ & & 1,6 & \\
\hline
\end{tabular}


"Personel güçlendirme algısının hizmet kalitesi üzerinde olumlu yönde anlamlı bir etkisi vardır" şeklinde geliştirilen araştırmanın ikinci hipotezinde, algılanan örgütsel destek boyutları bağımsız, hizmet kalitesi alt boyutları tek tek bağımlı değişken olarak ele alınmıştır. Personel güçlendirme boyutlarının hizmet kalitesi boyutları üzerindeki etkisini belirlemek amaciyla yapılan basit doğrusal regresyon analizinin sonuçları Tablo 2'de özetlenmektedir. Analiz sonuçlarına göre, personel güçlendirme algısının hizmet kalitesi üzerindeki etkisini ölçmek için kurulan her bir modelin anlamlı olduğu ve değişkenler arasında pozitif yönlü bir ilişki olduğu saptanmıştır.

Tablo 2. Personel Güçlendirme Boyutlarının Hizmet Kalitesi Boyutlarına Etkisi

\begin{tabular}{|c|c|c|c|c|c|c|}
\hline \multirow[t]{2}{*}{ Bağımlı Değişken } & \multirow{2}{*}{$\begin{array}{c}\text { Model (Sabit) } \\
\text { ve Bağımsız } \\
\text { Değişken }\end{array}$} & \multicolumn{2}{|c|}{$\begin{array}{c}\text { Standardize } \\
\text { Edilmemiş } \\
\text { Katsayılar }\end{array}$} & \multirow{2}{*}{$\begin{array}{r}\begin{array}{r}\text { Standardize } \\
\text { Katsayilar }\end{array} \\
\text { Beta }\end{array}$} & \multirow{2}{*}{ T Değeri } & \multirow{2}{*}{$\begin{array}{l}\text { Anlam } \\
\text { Düzeyi }\end{array}$} \\
\hline & & Beta & $\begin{array}{l}\text { Std. } \\
\text { Hata }\end{array}$ & & & \\
\hline \multirow[b]{2}{*}{ Sorumluluk ve Empati } & (Sabit) & 3,565 & ,102 & & 34,874 & 000 \\
\hline & Etki & 197 & 025 & 349 & 7,853 & 000 \\
\hline \multicolumn{7}{|c|}{ R: ,349; R²: ,122; Düzeltilmiş R2: ,120; Model için F: 61,671; $p=$ =,000; D-W: 1,755 } \\
\hline \multirow[b]{2}{*}{$\begin{array}{l}\text { Güven Verme ve Özen } \\
\text { Gösterme }\end{array}$} & (Sabit) & 3,514 & 120 & & 29,371 & 000 \\
\hline & Etki & 213 & 029 & ,325 & 7,257 & , 000 \\
\hline \multicolumn{7}{|c|}{ R: ,325; R2: ,106; Düzeltilmiş R2: ,104; Model için F: 52,669; p= ,000; D-W: 1,567 } \\
\hline \multirow[b]{2}{*}{ Sorumluluk ve Empati } & (Sabit) & 2,197 & 151 & & 14,521 & , 000 \\
\hline & \begin{tabular}{|l} 
Özerklik ve \\
Yeterlilik
\end{tabular} & 492 & 034 & ,562 & 14,340 & 000 \\
\hline \multicolumn{7}{|c|}{ R: ,562; R2: ,316; Düzeltilmiş R2: ,315; Model için F: 205,632; p= ,000; D-W: 1,873 } \\
\hline \multirow[b]{2}{*}{$\begin{array}{l}\text { Güven Verme ve Özen } \\
\text { Gösterme }\end{array}$} & (Sabit) & 2,089 & 182 & & 11,460 & ,000 \\
\hline & \begin{tabular}{|l} 
Özerklik ve \\
Yeterlilik
\end{tabular} & ,520 & 041 & ,512 & 12,572 & 000 \\
\hline \multicolumn{7}{|c|}{ R: ,512; R2: ,262; Düzeltilmiş R2: ,260; Model için F: 158,051; p= ,000; D-W: 1,750 } \\
\hline \multirow[b]{2}{*}{ Sorumluluk ve Empati } & (Sabit) & 2,300 & 137 & & 16,780 & 000 \\
\hline & Anlam & 463 & 031 & ,582 & 15,096 & ,000 \\
\hline \multicolumn{7}{|c|}{ R: ,582; R2: ,339; Düzeltilmiş R2: ,337; Model için F: 227,889; $p=$ =,000; D-W: 1,904 } \\
\hline \multirow[b]{2}{*}{$\begin{array}{l}\text { Güven Verme ve Özen } \\
\text { Gösterme }\end{array}$} & (Sabit) & 2,101 & 163 & & 12,904 & ,000 \\
\hline & Anlam & ,511 & 036 & ,554 & 14,025 & ,000 \\
\hline
\end{tabular}

Tablo 2 incelendiğinde, etki boyutunun sorumluluk ve empati üzerindeki etkisi ( $\mathrm{F}=61,671$, $\mathrm{p}=, 000$ ) istatistiki olarak anlamlı bulunmuştur. $\mathrm{R}$ değerinin ,349 olması, değişkenler arasında düşük pozitif bir ilişki olduğunu göstermektedir. $\mathrm{R}^{2}, 122$ olarak hesaplanmıştır. Bu durumda, çalışanların sorumluluk ve empatiye ilişkin algılarındaki değişkenliğin \% 12,2'sinin bağımsız değişken olan etki ile açıklandığı ifade edilebilir. Etki boyutunun güven verme ve özen gösterme boyutu üzerindeki etkisi ( $\mathrm{F}=52,669, \mathrm{p}=, 000)$ de istatistiki olarak anlamlı bulunmuştur. $R$ değerinin ,325 olması, değişkenler arasında düşük pozitif bir ilişki olduğunu göstermektedir. $\mathrm{R}^{2}, 106$ olarak 
hesaplanmıştır. Bu durumda, çalışanların güven verme ve özen göstermeye ilişkin algılarındaki değişkenliğin \% 10,6'sının bağımsız değişken olan etki ile açıklandığı ifade edilebilir. Dolayısıyla personel güçlendirmenin, hizmet kalitesinin tespit edilen tüm boyutları üzerindeki etkisinin pozitif yönlü ve anlamlı olduğu anlaşılmaktadır.

Araştırmanın üçüncü hipotezi "Örgütsel destek algısının personel güçlendirme algisı üzerinde olumlu yönde anlamlı bir etkisi vardır" şeklinde geliştirilmiştir. Söz konusu hipotezin test edilmesi sonucunda, örgütsek destek boyutlarından olan önemsenme, göz ardı edilme, gözden çıkarılma ve gururlandırma boyutlarının personel güçlendirme boyutları olan etki, anlam ve özerklik ve yeterlilik boyutları üzerinde anlamlı bir etkisi olduğu saptanmıştır. Öte yandan, maaşla ödüllendirme ve anlayışla karşılama örgütsel destek boyutunun personel güçlendirme boyutlarından olan anlam boyutu üzerinde anlamlı bir etki varken, özerklik ve yeterlilik boyutu üzerinde ise istatistiksel olarak anlamlı bir etkisi olmadığı tespit edilmiştir.Yapılan regresyon analizi sonuçları Tablo 3'te özetlenmektedir.

Tablo 3 incelendiğinde, önemsenme boyutunun etki üzerindeki etkisi $(F=112,089, p=, 000)$ istatistiki olarak anlamlı bulunmuştur. $R$ değerinin ,449 olması, değişkenler arasında orta düzey pozitif bir ilişki olduğunu göstermektedir. $\mathrm{R}^{2}$,201 olarak hesaplanmıştır. Bu durumda, çalışanların etkiye ilişkin algılarındaki değişkenliğin \% 20,1'inin bağımsız değişken olan önemsenme ile açıklandığı ifade edilebilir. Aynı analizde önemsenme boyutunun özerklik ve yeterlilik üzerindeki etkisi ( $\mathrm{F}=40,586, \mathrm{p}=, 000)$ istatistiki olarak anlamlı bulunmuştur. $\mathrm{R}$ değerinin ,289 olması, değişkenler arasında düşük pozitif bir ilişki olduğunu göstermektedir. $\mathrm{R}^{2}, 084$ olarak hesaplanmıştır. Bu durumda, çalışanların özerklik ve yeterliliğe ilişkin algılarındaki değişkenliğin \% 8,4'ünün bağımsız değişken olan önemsenme ile açıklandığı belirtilebilir.

Maaşla ödüllendirme ve anlayışla karşıllanma boyutunun etki üzerindeki etkisi ( $F=28,762$, p=,000) istatistiki olarak anlamlı bulunmuştur. $\mathrm{R}$ değerinin ,246 olması, değişkenler arasında düşük pozitif bir ilişki olduğunu göstermektedir. $\mathrm{R}^{2}, 061$ olarak hesaplanmıştır. Bu durumda, çalışanların etkiye ilişkin algılarındaki değişkenliğin \% 6,1'inin bağımsız değişken olan maaşla ödüllendirme ve anlayışla karşılanma ile açıklandığı ifade edilebilir. Öte yandan, maaşla ödüllendirme ve anlayışla karşılanma boyutunun özerklik ve yeterlilik üzerindeki etkisinin $(\mathrm{F}=2,485, \quad \mathrm{p}=, 116)$ istatistiki olarak anlamlı olmadığı görülmüştür. Dolayısıyla, maaşla ödüllendirme ve anlayışla karşılanma ile özerklik yeterlilik algısı arasında anlamlı bir ilişkinin bulunmadığı anlaşılmaktadır. Model anlamsız çıtığı için, sonuca dönük basit doğrusal regresyon modeli kurulamamıştır.

Araştırmada test edilmek üzere geliştirilen son hipotez ise " Örgütsel destek algısının hizmet kalitesine etkisinde personel güçlendirmenin aracılık rolü vardır" şeklinde geliştirilmiştir. Örgütsel destek ile hizmet kalitesi arasındaki ilişkide personel güçlendirmenin aracılık etkisini incelemek için Baron ve Kenny'in üç aşamalı regresyon analizi uygulanmıştır. Baron ve Kenny'in üç aşamalı regresyon analizine göre üç koşulun sağlanması gerekmektedir. Birinci koşula göre bağımsız değişkenin aracı değişken üzerinde etkisi olduğu istatistiki olarak anlamlı olmalıdır. Ikinci koşula göre bağımsız değişkenin bağımlı değişken üzerinde etkisi olduğu istatistiki olarak anlamlı olmalıdır. Üçüncü koşul ise, bağımsız değişkenin bağımlı değişken üzerindeki etkisinde modele dahil edilmesi durumunda aracı değişkenin aracılık etkisi istatistiki olarak anlamlı olmalıdır (Baron ve Kenny, 1986:1177). Bu bağlamda aracılık etkisini yapmak için yapılan regresyon analizi sonuçlarına göre örgütsel desteğin hizmet kalitesine etkisinde personel güçlendirmenin kısmi aracılık etkisi olduğu tespit edilmiştir (Ek-9'a Bkz.) 
Tablo 3. Algılanan Örgütsel Destek Boyutlarının Personel Güçlendirme Boyutlarına Etkisi

\begin{tabular}{|c|c|c|c|c|c|c|}
\hline \multirow[t]{2}{*}{ Bağımlı Değişken } & \multirow{2}{*}{$\begin{array}{l}\text { Model (Sabit) ve } \\
\text { Bağımsız Değişken }\end{array}$} & \multicolumn{2}{|c|}{$\begin{array}{c}\text { Standardize } \\
\text { Edilmemiş Katsayılar }\end{array}$} & \multirow{2}{*}{$\begin{array}{c}\begin{array}{r}\text { Standardize } \\
\text { Katsayllar }\end{array} \\
\text { Beta }\end{array}$} & \multirow[b]{2}{*}{ T Değeri } & \multirow{2}{*}{$\begin{array}{l}\text { Anlam } \\
\text { Düzeyi }\end{array}$} \\
\hline & & Beta & $\begin{array}{l}\text { Std. } \\
\text { Hata }\end{array}$ & & & \\
\hline \multirow[b]{2}{*}{ Etki } & (Sabit) & 2,156 &, 178 & & 12,139 & 000 \\
\hline & Önemsenme &, 504 & ,048 & 449 & 10,587 & ,000 \\
\hline \multicolumn{7}{|c|}{ R: ,449; R2: ,201; Düzeltilmiş R2: ,199; Model için F: 112,089; p= ,000; D-W: 1,858 } \\
\hline \multirow[t]{2}{*}{ Özerklik ve Yeterlilik } & (Sabit) & 3,610 &, 122 & & 29,502 & 000 \\
\hline & Önemsenme & 209 &, 033 & 289 & 6,371 & 000 \\
\hline \multicolumn{7}{|c|}{ R: ,289; R²: ,084; Düzeltilmiş R2: ,082; Model için F: 40,586; p= ,000; D-W: 1,881 } \\
\hline \multirow[t]{2}{*}{ Anlam } & (Sabit) & 3,478 &, 133 & & 26,157 & 000 \\
\hline & Önemsenme & 260 &, 036 & ,327 & 7,302 & 000 \\
\hline \multicolumn{7}{|c|}{ R: ,327; R²: ,107; Düzeltilmiş R2: ,105; Model için F: 53,313; p= ,000; D-W: 1,807 } \\
\hline \multirow[t]{2}{*}{ Etki } & (Sabit) & 3,422 &, 151 & & 22,606 & 000 \\
\hline & Göz Ardı Edilme Dur. & 178 &, 045 & 184 & 3,946 &, 000 \\
\hline \multicolumn{7}{|c|}{ R: ,184; R²: ,034; Düzeltilmiş R2: ,032; Model için F: 15,574; p= ,000; D-W: 1,837 } \\
\hline \multirow[t]{2}{*}{ Özerklik ve Yeterlilik } & (Sabit) & 4,170 & ,099 & & 42,312 & 000 \\
\hline & Göz Ardı Edilme Dur. & 063 & ,029 & 101 & 2,149 & 032 \\
\hline \multicolumn{7}{|c|}{ R: ,101; R2: ,010; Düzeltilmiş R2: ,008; Model için F: 4,617; p= ,032; D-W: 1,949 } \\
\hline \multirow[t]{2}{*}{ Anlam } & (Sabit) & 4,086 &, 108 & & 37,929 & 000 \\
\hline & Göz Ardı Edilme Dur. & 106 & 032 & 155 & 3,301 & 001 \\
\hline \multicolumn{7}{|c|}{ R: ,155; R²: ,024; Düzeltilmiş R2: ,022; Model için F: 10,899; p= ,001; D-W: 1,827 } \\
\hline \multirow[t]{2}{*}{ Etki } & (Sabit) & 3,259 & 161 & & 20,182 & 000 \\
\hline & Gözden Çıkarılma Dur. & 219 & ,049 & 219 & 4,728 &, 000 \\
\hline \multicolumn{7}{|c|}{ R: ,219; R²: ,048; Düzeltilmiş R2: ,046; Model için F: 22,350; p= ,000; D-W: 1,819 } \\
\hline \multirow[t]{2}{*}{ Özerklik ve Yeterlilik } & (Sabit) & 3,950 &, 104 & & 37,839 & , 000 \\
\hline & Gözden Çıkarılma Dur. & ,126 &, 030 & ,195 & 4,191 & 000 \\
\hline \multicolumn{7}{|c|}{ R: ,195; R2: ,038; Düzeltilmiş R2: ,036; Model için F: 17,561; p= ,000; D-W: 1,942 } \\
\hline \multirow[t]{2}{*}{ Anlam } & (Sabit) & 3,905 &, 114 & & 34,160 & , 000 \\
\hline & Gözden Çıkarılma Dur. & ,155 & ,033 & 219 & 4,731 & 000 \\
\hline & R: ,219; R2: ,048; Düzel & miş $\mathrm{R}^{2}:, 0$ & del için & 2,$385 ; \mathrm{p}=, 000 ;$ & $W: 1,807$ & \\
\hline Etki & (Sabit) & 2,565 &, 192 & & 13,331 &, 000 \\
\hline & Gururlandirma & ,394 & ,052 & 339 & 7,601 & 000 \\
\hline & R: ,339; R2: ,115; Düzel & miş $R^{2}:, 1$ & del için & 7,$775 ; \mathrm{p}=, 000 ;$ & $N: 1,849$ & \\
\hline Özerklik ve Yeterlilik & (Sabit) & 3,692 &, 127 & & 28,994 & ,000 \\
\hline & Gururlandirma & ,187 &, 034 & ,251 & 5,465 & ,000 \\
\hline & R: ,251; R²: ,063; Düzel & miş $R^{2}:, 0$ & del için & 9,$863 ; \mathrm{p}=, 000 ;$ & $W: 1,946$ & \\
\hline Anlam & (Sabit) & 3,635 &, 140 & & 26,036 & 000 \\
\hline & Gururlandırma & 218 &, 038 & ,265 & 5,809 & ,000 \\
\hline & R: ,265; R²: ,070; Düzell & miş $R^{2}:, 0$ & del için & 3,$740 ; \mathrm{p}=, 000 ;$ & $W: 1,819$ & \\
\hline Etki & (Sabit) & 3,253 &, 144 & & 22,520 & 000 \\
\hline & \begin{tabular}{|l|} 
Maaşla Ödüllendirme ve \\
Anlayışla Karşılanma
\end{tabular} & 246 &, 046 & ,246 & 5,363 & ,000 \\
\hline & R: ,246; R²: ,061; Düzel & niş $R^{2}:, 0$ & del için & 8,$762 ; \mathrm{p}=, 000 ;$ & $W: 1,844$ & \\
\hline Özerklik ve Yeterlilik & (Sabit) & 4,229 &, 096 & & 44,244 & , 000 \\
\hline & $\begin{array}{l}\text { Maaşla Ödüllendirme ve } \\
\text { Anlayışla Karşılanma }\end{array}$ & ,048 &, 030 & ,075 & 1,576 & ,116 \\
\hline & R: ,075; R²: ,006; Düzel & Imiş R2: ,0 & del içir & $485 ; p=, 116 ;$ & $W: 1,943$ & \\
\hline Anlam & (Sabit) & 3,984 &, 103 & & 38,600 & ,000 \\
\hline & $\begin{array}{l}\text { Maaşla Ödüllendirme ve } \\
\text { Anlayışla Karşılanma }\end{array}$ & 147 & ,033 & 208 & 4,482 & ,000 \\
\hline
\end{tabular}


Araştırmada, örgütsel desteğin hizmet kalitesine etkisinde personel güçlendirmenin aracılık etkisini belirlemeye ilişkin yapılan çoklu regresyon analizine göre Baron ve Kenny (1986)'in üç aşamalı regresyon analizine ilişkin üç koşulun sağlandığı tespit edilmiştir. Birinci koşula göre örgütsel desteğin (bağımsız değişkenin) personel güçlendirme (aracı değişken) üzerindeki etkisi (etki boyutu için $\mathrm{F}=23,200$, p=,000; özerklik ve yeterlilik boyutu için $\mathrm{F}$ : 12,575, p=,000; anlam boyutu için $\mathrm{F}: 11,177, \mathrm{p}=, 000$ ) istatistiki olarak anlamlı bulunmuştur. Ikinci koşula göre örgütsel desteğin (bağımsız değişkenin) hizmet kalitesi (bağımlı değişken) üzerinde etkisi (sorumluluk ve empati boyutu için $F=8,809$, $p=, 000$; güven verme ve özen gösterme boyutu için $7,844, p=, 000$ ) istatistiki olarak anlamlı bulunmuştur. Üçüncü koşula göre, örgütsel desteğin (bağımsız değişkenin) hizmet kalitesi (bağımlı değişken) üzerindeki etkisinde modele dahil edilen personel güçlendirmenin (aracı değişkenin) aracılık etkisi (sorumluluk ve empati boyutu için $\mathrm{F}=41,850$, $\mathrm{p}=, 000$; güven verme ve özen gösterme boyutu için $\mathrm{F}: 32,579, \mathrm{p}=, 000)$ istatistiki olarak anlamlı bulunmuştur (Ek-1, Ek-2, Ek-3, Ek-4, Ek-5, Ek-6, Ek-7'ye Bkz.).

Çalışmada ayrıca aracılık etkisinin anlamlı olup olmadığını belirlemeye ilişkin Sobel tarafından geliştirilen ve kendi adıyla anılan Sobel testi yapılmıştır. Sobel testinin formülü $z=a b / \sqrt{ }\left(b^{2} S_{a^{2}}+\right.$ $\left.a^{2} S b^{2}\right)^{\prime}$ dir (Baron ve Kenny, 1986:1177). Sobel testi için gerekli olan a (standardize edilmemiş $\beta$ ) ve Sa ( $\beta$ değerinin standart hatası) değerleri Tablo 1, Tablo 2, Tablo 3'te yer almaktadır. Söz konusu değerler, Sobel testi için verilen formülde yerine konup hesaplandığında, Tablo 4 'te genel olarak z değerlerinin anlamlı olduğu $(P<0,01)$ sonucuna varılmıştır (Ek-8'e bkz.).

Sobel testine ilişkin aracılık etkisi modeli Şekil 2'de yer almaktadır. Bu kapsamda, araştırmanın aracılık etkisinin anlamlı olup olmadığını test etmek için araştırmanın modeli sobel testine göre uyarlanmış; Şekil 3'te yer almaktadır.

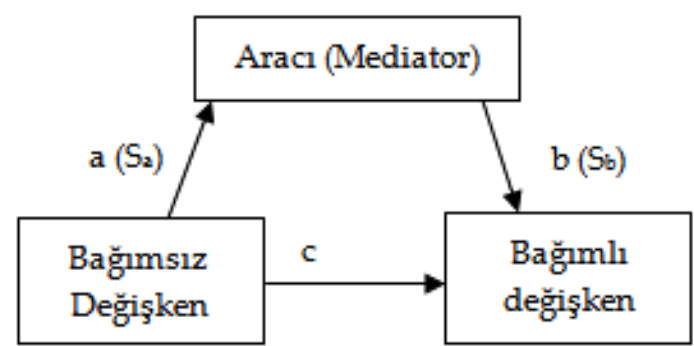

Şekil 2. Sobel Testi Modeli

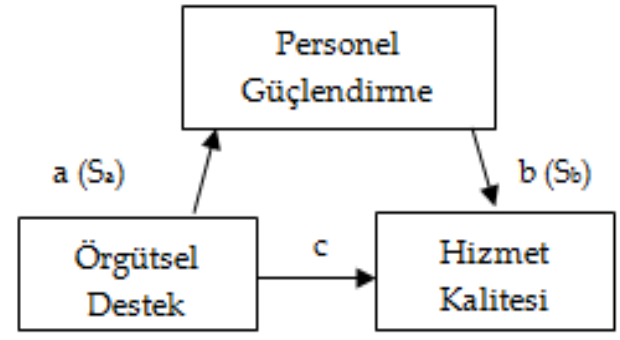

Şekil 3. Araştırmanın Sobel Testi Modeli

Şekil 2 ve Şekil 3'e göre örgütsel destek (bağımsız değişken) ile personel güçlendirme (aracı değişken) değişkenlerine ilişkin yapılan regresyon analizlerinde boyutlara ait standardize edilmemiş $\beta$ ve $\beta$ değerinin standart hatası ile personel güçlendirme (aracı değişken) ile hizmet kalitesi (aracı değişken) değişkenlerine ilişkin yapılan regresyon analizlerinde boyutlara ait standardize edilmemiş $\beta$ ve $\beta$ değerinin standart hatası, sobel testi formülünde kullanılıp Tablo4'te aracılık etkisinin anlamlılığı belirlenmiştir.

Tablo 4'te sobel testinin $\mathrm{z}$ değeri ve anlamlılık düzeyleri ile örgütsel desteğin personel güçlendirme boyutları üzerindeki etkisini belirlemeye ilişkin Tablo1,Tablo 2, Tablo3'te yer alan regresyon analizine ait katsayılar incelendiğinde boyutlara ilişkin anlamlılık düzeyleri paralellik göstermektedir. Bu durumda, sobel testi, örgütsel desteğin hizmet kalitesine etkisinde personel güçlendirmenin kısmi aracılık etkisini destekler niteliktedir. 
Tablo 4. Örgütsel Desteğin Hizmet Kalitesine Etkisinde Personel Güçlendirmenin Aracılık Etkisinin Anlamlılığını Test Etmeye İlişkin Sobel Testi

\begin{tabular}{|c|c|c|c|c|c|c|}
\hline $\begin{array}{l}\text { Bağımsız ve } \\
\text { Bağımlı } \\
\text { değişkenler }\end{array}$ & $\begin{array}{c}\text { Aracı } \\
\text { değişkenler }\end{array}$ & $\begin{array}{l}\text { Standardize } \\
\text { edilmemiş } \beta \\
\text { (a) }\end{array}$ & $\begin{array}{c}\beta \text { değerinin } \\
\text { standart } \\
\text { hatası }(\mathrm{Sa})\end{array}$ & $\begin{array}{l}\text { Standardize } \\
\text { edilmemiş } \beta \\
\text { (b) }\end{array}$ & $\begin{array}{c}\beta \\
\text { değerinin } \\
\text { standart } \\
\text { hatası }(\mathrm{Sb})\end{array}$ & z değeri \\
\hline Önemsenme & $P G$ (etki) & ,504 & ,048 & - & - & - \\
\hline $\begin{array}{c}\text { HK (Sorumluluk } \\
\text { ve Empati) }\end{array}$ & PG (etki) & - & - & ,174 & ,028 & $\begin{array}{c}5,3478 \\
(p<0,01)\end{array}$ \\
\hline Önemsenme & $\begin{array}{l}\text { PG (özerklik } \\
\text { ve yeterlilik) }\end{array}$ & 209 & ,033 & - & - & - \\
\hline $\begin{array}{l}\text { HK (Sorumluluk } \\
\text { ve Empati) }\end{array}$ & $\begin{array}{l}\text { PG (özerklik } \\
\text { ve yeterlilik) }\end{array}$ & - & - & 474 & ,039 & $\begin{array}{r}5,6165 \\
(p<0,01) \\
\end{array}$ \\
\hline Önemsenme & $P G($ anlam) & ,260 & , 036 & - & - & - \\
\hline $\begin{array}{l}\text { HK (Sorumluluk } \\
\text { ve Empati) }\end{array}$ & PG (anlam) & - & - & ,452 & ,032 & $\begin{array}{c}6,4304 \\
(p<0,01)\end{array}$ \\
\hline Önemsenme & $P G$ (etki) & ,504 & ,048 & - & - & - \\
\hline $\begin{array}{c}\text { HK (Güven } \\
\text { Verme ve Özen } \\
\text { Gösterme) }\end{array}$ & PG (etki) & - & - & , 166 & ,032 & $\begin{array}{c}4,6508 \\
(p<0,01)\end{array}$ \\
\hline Önemsenme & $\begin{array}{l}\text { PG (özerklik } \\
\text { ve yeterlilik) }\end{array}$ & 209 & ,033 & - & - & - \\
\hline $\begin{array}{c}\text { HK (Güven } \\
\text { Verme ve Özen } \\
\text { Gösterme) }\end{array}$ & $\begin{array}{l}\text { PG (özerklik } \\
\text { ve yeterlilik) }\end{array}$ & - & - & 480 & ,043 & $\begin{array}{c}5,5084 \\
(p<0,01)\end{array}$ \\
\hline Önemsenme & $P G($ anlam $)$ & 260 & 036 & - & - & - \\
\hline $\begin{array}{c}\text { HK (Güven } \\
\text { Verme ve Özen } \\
\text { Gösterme) } \\
\end{array}$ & PG (anlam) & - & - & 480 & ,038 & $\begin{array}{c}6,2697 \\
(p<0,01)\end{array}$ \\
\hline $\begin{array}{c}\text { Göz Ardı Edilme } \\
\text { Durumu }\end{array}$ & $P G$ (etki) & 178 & ,045 & - & - & - \\
\hline $\begin{array}{c}\text { HK (Sorumluluk } \\
\text { ve Empati) }\end{array}$ & PG (etki) & - & - & , 188 & ,025 & $\begin{array}{c}3,5007 \\
(p<0,01)\end{array}$ \\
\hline $\begin{array}{c}\text { Göz Ardı Edilme } \\
\text { Durumu }\end{array}$ & $\begin{array}{l}\text { PG (özerklik } \\
\text { ve yeterlilik) }\end{array}$ & ,063 & ,029 & - & - & - \\
\hline $\begin{array}{c}\text { HK (Sorumluluk } \\
\text { ve Empati) }\end{array}$ & $\begin{array}{l}\text { PG (özerklik } \\
\text { ve yeterlilik) }\end{array}$ & - & - & 485 & ,034 & $\begin{array}{c}2,1476 \\
(p>0,01)\end{array}$ \\
\hline $\begin{array}{c}\text { Göz Ardı Edilme } \\
\text { Durumu }\end{array}$ & PG (anlam) & 106 & , 032 & - & - & - \\
\hline $\begin{array}{c}\text { HK (Sorumluluk } \\
\text { ve Empati) }\end{array}$ & PG (anlam) & - & - & ,456 & ,031 & $\begin{array}{c}3,2315 \\
(p<0,01) \\
\end{array}$ \\
\hline $\begin{array}{c}\text { Göz Ardı Edilme } \\
\text { Durumu }\end{array}$ & $P G($ etki) & 178 & ,045 & - & - & - \\
\hline $\begin{array}{c}\text { HK (Güven } \\
\text { Verme ve Özen } \\
\text { Gösterme) } \\
\end{array}$ & PG (etki) & - & - & 201 & ,030 & $\begin{array}{c}3,4062 \\
(p<0,01)\end{array}$ \\
\hline $\begin{array}{c}\text { Göz Ardı Edilme } \\
\text { Durumu }\end{array}$ & $\begin{array}{l}\text { PG (özerklik } \\
\text { ve yeterlilik) }\end{array}$ & ,063 & ,029 & - & - & - \\
\hline $\begin{array}{c}\text { HK (Güven } \\
\text { Verme ve Özen } \\
\text { Gösterme) }\end{array}$ & $\begin{array}{l}\text { PG (özerklik } \\
\text { ve yeterlilik) }\end{array}$ & - & - & ,509 & ,041 & $\begin{array}{c}2,1398 \\
(p>0,01)\end{array}$ \\
\hline $\begin{array}{c}\text { Göz Ardı Edilme } \\
\text { Durumu }\end{array}$ & PG (anlam) & 106 & ,032 & - & - & - \\
\hline $\begin{array}{c}\text { HK (Güven } \\
\text { Verme ve Özen } \\
\text { Gösterme) }\end{array}$ & PG (anlam) & - & - &, 501 & ,037 & $\begin{array}{c}3,2176 \\
(p<0,01)\end{array}$ \\
\hline $\begin{array}{c}\text { Gözden Çıkarılma } \\
\text { Durumu }\end{array}$ & $P G($ etki) & ,219 & ,049 & - & - & - \\
\hline $\begin{array}{c}\text { HK (Sorumluluk } \\
\text { ve Empati) }\end{array}$ & PG (etki) & - & - & , 180 & ,025 & $\begin{array}{c}3,7972 \\
(p<0,01)\end{array}$ \\
\hline
\end{tabular}




\begin{tabular}{|c|c|c|c|c|c|c|}
\hline $\begin{array}{c}\text { Gözden Çıkarılma } \\
\text { Durumu }\end{array}$ & $\begin{array}{l}\text { PG (özerklik } \\
\text { ve yeterlilik) }\end{array}$ & ,126 & , 030 & - & - & - \\
\hline $\begin{array}{c}\text { HK (Sorumluluk } \\
\text { ve Empati) }\end{array}$ & $\begin{array}{l}\text { PG (özerklik } \\
\text { ve yeterlilik) }\end{array}$ & - & - & ,475 & ,035 & $\begin{array}{r}4,0122 \\
(p<0,01) \\
\end{array}$ \\
\hline $\begin{array}{c}\text { Gözden Çıkarılma } \\
\text { Durumu }\end{array}$ & $P G$ (anlam) & ,155 & ,033 & - & - & - \\
\hline $\begin{array}{l}\text { HK (Sorumluluk } \\
\text { ve Empati) }\end{array}$ & PG (anlam) & - & - & ,448 & ,031 & $\begin{array}{r}4,4669 \\
(\mathrm{p}<0,01)\end{array}$ \\
\hline $\begin{array}{c}\text { Gözden Çıkarılma } \\
\text { Durumu }\end{array}$ & $P G($ etki) & 219 &, 049 & - & - & - \\
\hline $\begin{array}{c}\text { HK (Güven } \\
\text { Verme ve Özen } \\
\text { Gösterme) }\end{array}$ & PG (etki) & - & - & 197 & ,030 & $\begin{array}{c}3,6947 \\
(p<0,01)\end{array}$ \\
\hline $\begin{array}{c}\text { Gözden Çıkarılma } \\
\text { Durumu }\end{array}$ & $\begin{array}{l}P G \text { (özerklik } \\
\text { ve yeterlilik) }\end{array}$ & ,126 & , 030 & - & - & - \\
\hline $\begin{array}{c}\text { HK (Güven } \\
\text { Verme ve Özen } \\
\text { Gösterme) } \\
\end{array}$ & $\begin{array}{l}\text { PG (özerklik } \\
\text { ve yeterlilik) }\end{array}$ & - & - &, 505 &, 042 & $\begin{array}{l}3,9650 \\
(p<0,01)\end{array}$ \\
\hline $\begin{array}{c}\text { Gözden Çıkarılma } \\
\text { Durumu }\end{array}$ & $P G$ (anlam) & ,155 & ,033 & - & - & - \\
\hline $\begin{array}{l}\text { HK (Güven } \\
\text { Verme ve Özen } \\
\text { Gösterme) } \\
\end{array}$ & PG (anlam) & - & - &, 500 & ,037 & $\begin{array}{l}4,4366 \\
(\mathrm{p}<0,01)\end{array}$ \\
\hline Gururlandirma & $P G($ etki) & 219 & , 049 & - & - & - \\
\hline $\begin{array}{c}\text { HK (Sorumluluk } \\
\text { ve Empati) }\end{array}$ & PG (etki) & - & - & 170 & ,026 & $\begin{array}{c}3,6897 \\
(\mathrm{p}<0,01) \\
\end{array}$ \\
\hline Gururlandırma & $\begin{array}{l}\text { PG (özerklik } \\
\text { ve yeterlilik) }\end{array}$ & ,126 & , 030 & - & - & - \\
\hline $\begin{array}{c}\text { HK (Sorumluluk } \\
\text { ve Empati) }\end{array}$ & $\begin{array}{l}\text { PG (özerklik } \\
\text { ve yeterlilik) }\end{array}$ & - & - & ,469 & ,035 & $\begin{array}{c}4,0077 \\
(p<0,01) \\
\end{array}$ \\
\hline Gururlandirma & $P G$ (anlam) & ,155 & , 033 & - & - & - \\
\hline $\begin{array}{l}\text { HK (Sorumluluk } \\
\text { ve Empati) }\end{array}$ & PG (anlam) & - & - & 444 & , 032 & $\begin{array}{r}4,4489 \\
(\mathrm{p}<0,01) \\
\end{array}$ \\
\hline Gururlandirma & $P G(e t k i)$ & 219 &, 049 & - & - & - \\
\hline $\begin{array}{l}\text { HK (Güven } \\
\text { Verme ve Özen } \\
\text { Gösterme) } \\
\end{array}$ & PG (etki) & - & - & ,182 & ,031 & $\begin{array}{c}3,5561 \\
(p<0,01)\end{array}$ \\
\hline Gururlandirma & $\begin{array}{l}\text { PG (özerklik } \\
\text { ve yeterlilik) }\end{array}$ & ,126 & , 030 & - & - & - \\
\hline $\begin{array}{l}\text { HK (Güven } \\
\text { Verme ve Özen } \\
\text { Gösterme) }\end{array}$ & $\begin{array}{l}\text { PG (özerklik } \\
\text { ve yeterlilik) }\end{array}$ & - & - & 492 & ,042 & $\begin{array}{l}3,9535 \\
(p<0,01)\end{array}$ \\
\hline Gururlandirma & $P G$ (anlam) & ,155 & ,033 & - & - & - \\
\hline $\begin{array}{l}\text { HK (Güven } \\
\text { Verme ve Özen } \\
\text { Gösterme) }\end{array}$ & PG (anlam) & - & - & ,489 & ,038 & $\begin{array}{c}4,4122 \\
(p<0,01)\end{array}$ \\
\hline $\begin{array}{c}\text { Maaşla } \\
\text { Ödüllendirme ve } \\
\text { Anlayışla } \\
\text { Karşılanma }\end{array}$ & $P G($ etki) & ,246 & ,046 & - & - & - \\
\hline $\begin{array}{c}\text { HK (Sorumluluk } \\
\text { ve Empati) }\end{array}$ & PG (etki) & - & - & 198 & ,025 & $\begin{array}{r}4,4320 \\
(\mathrm{p}<0,01) \\
\end{array}$ \\
\hline $\begin{array}{c}\text { Maaşla } \\
\text { Ödüllendirme ve } \\
\text { Anlayışla } \\
\text { Karşılanma }\end{array}$ & $\begin{array}{l}\text { PG (özerklik } \\
\text { ve yeterlilik) }\end{array}$ & ,048 & , 030 & - & - & - \\
\hline $\begin{array}{l}\text { HK (Sorumluluk } \\
\text { ve Empati) }\end{array}$ & $\begin{array}{l}\text { PG (özerklik } \\
\text { ve yeterlilik) }\end{array}$ & - & - & ,490 & ,035 & $\begin{array}{c}1,5896 \\
(p>0,01)\end{array}$ \\
\hline $\begin{array}{c}\text { Maaşla } \\
\text { Ödüllendirme ve }\end{array}$ & $P G($ anlam) & ,147 & ,033 & - & - & - \\
\hline
\end{tabular}




\begin{tabular}{|c|c|c|c|c|c|c|}
\hline $\begin{array}{c}\text { Anlayış̧la } \\
\text { Karşılanma }\end{array}$ & & & & & & \\
\hline $\begin{array}{l}\text { HK (Sorumluluk } \\
\text { ve Empati) }\end{array}$ & PG (anlam) & - & - & 471 & 031 & $\begin{array}{c}4,2746 \\
(p<0,01)\end{array}$ \\
\hline $\begin{array}{c}\text { Maaşla } \\
\text { Ödüllendirme ve } \\
\text { Anlayışla } \\
\text { Karşılanma }\end{array}$ & $P G(e t k i)$ & 246 & ,046 & - & - & - \\
\hline $\begin{array}{l}\text { HK (Güven } \\
\text { Verme ve Özen } \\
\text { Gösterme) } \\
\end{array}$ & PG (etki) & - & - & 201 & 030 & $\begin{array}{c}4,1796 \\
(p<0,01)\end{array}$ \\
\hline $\begin{array}{c}\text { Maaşla } \\
\text { Ödüllendirme ve } \\
\text { Anlayışla } \\
\text { Karşılanma }\end{array}$ & $\begin{array}{l}\text { PG (özerklik } \\
\text { ve yeterlilik) }\end{array}$ & ,048 & ,030 & - & - & - \\
\hline $\begin{array}{l}\text { HK (Güven } \\
\text { Verme ve Özen } \\
\text { Gösterme) }\end{array}$ & $\begin{array}{l}\text { PG (özerklik } \\
\text { ve yeterlilik) }\end{array}$ & - & - &, 512 & ,042 & $\begin{array}{c}1,5863 \\
(p>0,01)\end{array}$ \\
\hline $\begin{array}{c}\text { Maaşla } \\
\text { Ödüllendirme ve } \\
\text { Anlayışla } \\
\text { Karşılanma }\end{array}$ & $P G$ (anlam) &, 147 & ,033 & - & - & - \\
\hline $\begin{array}{l}\text { HK (Güven } \\
\text { Verme ve Özen } \\
\text { Gösterme) }\end{array}$ & PG (anlam) & - & - &, 504 & ,037 & $\begin{array}{c}4,2339 \\
(p<0,01)\end{array}$ \\
\hline \multicolumn{7}{|c|}{ Sobel testinin formülü $z=a b / \sqrt{ }\left(b^{2} S a^{2}+a^{2} S b^{2}\right)$} \\
\hline \multicolumn{7}{|c|}{$\begin{array}{l}\text { PG: Personel Güçlendirme - HK : Hizmet Kalitesi } \\
\text { Örgütsel Destek Boyutu: Önemsenme, Göz ardı Edilme Durumu, Gözden Çıkarılma Durumu, Gururlandırma, } \\
\text { Maaşla Ödüllendirme ve Anlayışla Karşılanma } \\
\text { Personel Güçlendirme Boyutları: Etki, Özerklik ve Yeterlilik, Anlam } \\
\text { Hizmet Kalitesi Boyutları:Sorumluluk ve Empati, Güven Verme ve Özen Gösterme }\end{array}$} \\
\hline
\end{tabular}

\section{SONUÇ ve ÖNERILER}

Hizmet kalitesini ve işletme verimliliğini arttırmada önemli katkısı olan örgütsel destek ve personel güçlendirme son yıllarda önem kazanmış ve araştırmalara konu olmuştur. Araştırmanın temel amacı da, araştırma konusu olarak önem arz eden örgütsel desteğin hizmet kalitesine etkisinde turizm bölgesi olan Antalya'daki beş yıldızlı konaklama işletmelerinde personel güçlendirmenin aracılık etkisini belirlemektir. Bu kapsamda, yapılan analizlere ilişkin sonuçlara aşağıda değinilmektedir.

Örgütsel destek boyutlarının hizmet kalitesi boyutları üzerindeki etkisini matematiksel olarak ifade etmek amacıyla yapılan basit doğrusal regresyon analizi sonuçlarına göre çalışanların sorumluluk ve empatiye ilişkin algılarında değişkenliğin \% 5,2'sinin bağımsız değişken olan önemsenme ile açıklandığı; çalışanların güven verme ve özen göstermeye ilişkin algılarındaki değişkenliğin \% 7,4'ünün bağımsız değişken olan önemsenme ile açıklandığı ifade edilebilir. Çalışanların sorumluluk ve empatiye ilişkin algılarındaki değişkenliğin \% 2'sinin bağımsız değişken olan göz ardı edilme durumu ile açıklandığı; çalışanların güven verme ve özen göstermeye ilişkin algılarındaki değişkenliğin \% 2,4'ünün bağımsız değişken olan göz ardı edilme durumu ile açılandığı ifade edilebilir. Çalışanların sorumluluk ve empatiye ilişkin algılarındaki değişkenliğin \% 4,3'ünün bağımsız değişken olan gözden çıkarılma durumu ile açıklandığl; çalışanların güven verme ve özen göstermeye ilişkin algılarındaki değişkenliğin \% 3’ünün bağımsız değişken olan gözden çıkarılma durumu ile açıklandığı ifade edilebilir. Çalışanların sorumluluk ve empatiye ilişkin algılarındaki değişkenliğin \% 5,7'sinin bağımsız değişken olan gururlandırma ile açıklandığı; çalışanların güven verme ve özen göstermeye ilişkin 
algılarındaki değişkenliğin \% 5,4'ünün bağımsız değişken olan gururlandırma ile açıklandığ1 ifade edilebilir. Maaşla ödüllendirme ve anlayışla karşılanma ile sorumluluk ve empati algısı arasında anlamlı bir ilişkinin bulunmadığı anlaşılmaktadır. Model anlamsız çıktığı için, sonuca dönük basit doğrusal regresyon modeli kurulamamıştır. Çalışanların güven verme ve özen göstermeye ilişkin algılarındaki değişkenliğin \% 2,2'sinin bağımsız değişken olan maaşla ödüllendirme ve anlayışla karşılanma ile açıklandığı ifade edilebilir.

Örgütsel destek boyutlarının personel güçlendirme boyutları üzerindeki etkisini matematiksel olarak ifade etmek amacıyla yapılan basit doğrusal regresyon analizi sonuçlarına göre çalışanların etkiye ilişkin algılarındaki değişkenliğin \% 20,1'inin bağımsız değişken olan önemsenme ile açıklandığı; çalışanların özerklik ve yeterliliğe ilişkin algılarındaki değişkenliğin \% 8,4'ünün bağımsız değişken olan önemsenme ile açıklandığı; çalışanların anlama ilişkin algılarındaki değişkenliğin \% 10,7'sinin bağımsız değişken olan önemsenme ile açıklandığı ifade edilebilir. Çalışanların etkiye ilişkin algılarındaki değişkenliğin \% 3,4'ünün bağımsız değişken olan göz ardı edilme durumu ile açıklandı̆̆ı; çalışanların özerklik ve yeterliliğe ilişkin algılarındaki değişkenliğin \% 1'inin bağımsız değişken olan göz ardı edilme durumu ile açıklandığı; çalışanların anlama ilişkin algılarındaki değişkenliğin \% 2,4'ünün bağımsız değişken olan göz ardı edilme durumu ile açılandığı ifade edilebilir. Çalışanların etkiye ilişkin algılarındaki değişkenliğin \% 4,8'inin bağımsız değişken olan gözden çıkarılma durumu ile açıklandığı; çalışanların özerklik ve yeterliliğe ilişkin algılarındaki değişkenliğin \% 3,8'inin bağımsız değişken olan gözden çıkarılma durumu ile açıklandığı; çalışanların anlama ilişkin algılarındaki değişkenliğin \% 4,8'inin bağımsız değişken olan gözden çıkarılma durumu ile açıklandığ 1 ifade edilebilir. Çalışanların etkiye ilişkin algılarındaki değişkenliğin \% 11,5'inin bağımsız değişken olan gururlandırma ile açıklandığı; çalışanların özerklik ve yeterliliğe ilişkin algılarındaki değişkenliğin \% 6,3'ünün bağımsız değişken olan gururlandırma ile açıklandığı; çalışanların anlama ilişkin algılarındaki değişkenliğin \% 7'sinin bağımsız değişken olan gururlandırma ile açıklandığı ifade edilebilir. Çalışanların etkiye ilişkin algılarındaki değişkenliğin \% 6,1'inin bağımsız değişken olan maaşla ödüllendirme ve anlayışla karşılanma ile açıklandığı; çalışanların anlama ilişkin algılarındaki değişkenliğin \% 4,3'ünün bağımsız değişken olan maaşla ödüllendirme ve anlayışla karşılanma ile açıklandığı ifade edilebilir. Maaşla ödüllendirme ve anlayışla karşılanma ile özerklik yeterlilik algısı arasında anlamlı bir ilişkinin bulunmadığı anlaşılmaktadır. Model anlamsız çıktığı için, sonuca dönük basit doğrusal regresyon modeli kurulamamıştır.

Personel güçlendirme boyutlarının hizmet kalitesi boyutları üzerindeki etkisini matematiksel olarak ifade etmek amacıyla yapılan basit doğrusal regresyon analizi sonuçlarına göre çalışanların sorumluluk ve empatiye ilişkin algılarındaki değişkenliğin \% 12,2'sinin bağımsız değişken olan etki ile açıklandığı; çalışanların güven verme ve özen göstermeye ilişkin algılarındaki değişkenliğin \% 10,6'sının bağımsız değişken olan etki ile açıklandığı ifade edilebilir. Çalışanların sorumluluk ve empatiye ilişkin algılarındaki değişkenliğin \% 31,6'sının bağımsız değişken olan özerklik ve yeterlilik ile açıklandığı; çalışanların güven verme ve özen göstermeye ilişkin algılarındaki değişkenliğin \% 26,2'sinin bağımsız değişken olan özerklik ve yeterlilik ile açıklandığı ifade edilebilir. Çalışanların sorumluluk ve empatiye ilişkin algılarındaki değişkenliğin \% 33,9'unun bağımsız değişken olan anlam ile açıklandığı; çalışanların güven verme ve özen göstermeye ilişkin algılarındaki değişkenliğin \% 30,7'sinin bağımsız değişken olan anlama ile açıklandığı ifade edilebilir.

Örgütsel desteğin hizmet kalitesine etkisinde personel güçlendirmenin kısmi aracılık etkisi olduğu tespit edilmiştir. Araştırma kapsamında regresyon analizinin sonuçlarını desteklemeye ilişkin yapılan Tolerans ve VIF değerleri ile sobel testinin sonuçlarının aracılık etkisini desteklediğide görülmüştür. Bu bağlamda, araştırmada elde edilen bulgular sonucunda test 
edilmek üzere geliştirilen "Örgütsel destek algısının hizmet kalitesi üzerinde olumlu yöne anlamlı bir etkisi vardır", "Personel güçlendirmenin hizmet kalitesi üzerinde olumlu yöne anlamlı bir etkisi vardır", "Örgütsel destek algısının personel güçlendirme üzerinde olumlu yöne anlamlı bir etkisi vardır" ve "Örgütsel destek algısının hizmet kalitesine etkisinde personel güçlendirmenin aracılık rolü vardır" şeklindeki tüm hipotezlerin kabul edildiği tespit edilmiştir.

Literatürde örgütsel destek, hizmet kalitesi ve personel güçlendirme ile ilgili yapılan çalışmaların sonuçları incelendiğinde, Dimitriades ve Maroudas (2007: 391)'ın araştırmalarına göre personel güçlendirme ile hizmet kalitesi arasında pozitif yönlü anlamlı bir ilişki olduğunun tespit edilmesiyle araştırmanın hizmet kalitesi ve personel güçlendirmeye ilişkin analiz sonuçlarının paralellik gösterdiği görülmektedir. Personel güçlendirme ile hizmet kalitesi arasında pozitif anlamlı ilişkinin bulunduğu bir diğer çalışma da Samat vd., (2006: 723)' ne aittir.

Özbek ve Kosa (2010), örgütsel destek, üst yönetim desteği, duygusal bağlılık ve personel güçlendirmenin müşteri ile iletişim içerisinde olan işgörenlerin verdikleri hizmet kalitesi ile olan ilişkisini incelemeyi amaçladığı araştırma sonucunda, örgütsel desteğin ve personel güçlendirmenin hizmet kalitesi ile pozitif yönde anlamlı bir ilişki olduğunu tespit etmiştir. Özbek ve Kosa (2010)'nın araştırmalarındaki bu tespitin, araştırmanın hizmet kalitesi ile personel güçlendirme ve örgütsel desteğeye ilişkin analiz sonuçlarıyla paralellik gösterdiği ifade edilebilir.

Örgütsel destek, hizmet kalitesi ve personel güçlendirme değişkenleri arasındaki ilişkisinin belirlenmesine yönelik yerli ve yabancı literatürde daha önce yapılmış az sayıda çalışmaya rastlanmıştır. Bunun yanı sıra ağırlama endüstrisi bağlamında, örgütsel destek, hizmet kalitesi ve personel güçlendirme değişkenleri arasındaki ilişkisinin hiç incelenmediği görülmüştür. Dolayısıyla literatürdeki bu eksikliğinin giderilmesi için araştırmacılara; örgütsel destek, hizmet kalitesi ve personel güçlendirme değişkenleri arasındaki ilişkiyi farklı sektörlerde araştırmaları önerilir. Böylelikle bu değişkenler arasındaki ilişkinin tekrar çalışılması, değişkenler arasındaki ilişkilere dair yeni bulguların daha önceki bulgularla kıyaslanmasına imkan sağlayabilir ve bulguların güvenilirliği açısından önem arzedebilir.

Personel güçlendirme, örgütsel destek ve hizmet kalitesi değişkenlerinin birbiriyle ilişkisine yönelik tespitler işletmelere etkin hizmet kalitesi yönetimi konusunda faydalar sağlayabileceğinden, gerçek iş hayatında elde edilen veriler ve çıktılar sonucunda tespit edilen araştırma bulguları ileriye dönük yeni araştırmalar için kaynak oluşturabilir.

Örgütsel desteğin hizmet kalitesi ile ilişkisinde kritik öneme sahip olan örgütsel adalet, örgütsel bağlllık, örgütsel kimlik, lider-üye etkileşimi, yönetici desteği, iş tatmini ve kişilik özellikleri gibi değişkenlerle araştırılması, algılanan örgütsel desteğin hizmet kalitesi üzerindeki etkilerini açıklamaya katkı sağlayacaktır.

Personel güçlendirmenin hizmet kalitesi ile ilişkisinin araştırılması diğer önemli bulunan bir konudur. Hizmet kalitesi personel güçlendirmeden etkilenmektedir. Dolayısıyla personel güçlendirmenin hizmet kalitesine etkilerini açıklamaya katkı sağlayabileceği düşünülerek personel güçlendirmeyle ilişkili katılımcı yönetim ve motivasyon değişkenleri ile konunun araştırılması önerilir.

Araştırma farklı kültürlerdeki konaklama işletmelerindeki, diğer hizmet ve imalat işletmelerindeki işgörenler üzerinde çalışılarak hizmet kalitesi, örgütsel destek ve personel güçlendirme değişkenlerine ilişkin kültürler arası farklılıkların ve benzerliklerin kıyaslanmasına imkan sağlayabilir.

Araştırma işletmelerin hizmet kalitesini yükseltmede, örgüt içinde örgütsel destek ve personel güçlendirmeye ilişkin bazı standartları geliştirmeleri ve uygulatmaları açısından önemlidir. Böylece hizmet kalitesini arttırmaya ilişkin uygulamaları ile konaklama işletmeleri başarılı bir 
performans gösterebilir ve rekabet üstünlügünü sağlayabilir. İşletmeler için personel güçlendirme ve örgütsel destek uygulamalarını standartlaştırmaya ve iyileştirmeye uygun, hizmet kalitesini arttırmaya odaklı çağdaş bir yönetim modeli gerekli olabilmektedir. Bu da konaklama işletmelerinde mevcut iş akışlarının etkinliğini arttırarak ve daha çok işi daha kısa sürede yaparak, işgörenlerin daha yüksek performans göstermelerini sağlayıp onları takdir ederek sağlanabilir. Çağdaş bir yönetim modeli oluşturabilme bağlamında araştırma, kaliteyi arttırmada konaklama işletmelerine personel güçlendirme ve örgütsel destek algısını araştırmaya yönelik politikalar sunması açısından faydalı olabilir. Bu bağlamda hizmet kalitesini arttırmaya yönelik olarak örgütlere, işgörenleri için örgütsel destek ve personel güçlendirme bağlamında aşağıda belirtilen politikalar önerilebilir;

- Örgütlerin, örgütün performansını ve üretkenliğini yükseltmek için işgörenlerin iş ile ilgili bilgi, beceri, yetenek ve davranışlar edinmelerine yardımcı olacak eğitim programları düzenleyerek onları güçlendirmeleri ve işgörenlere edindikleri bilgi ve deneyimleri uygulama fırsatı vermeleri önerilir.

- Örgütlerde, işgörenlerin örgüte katkı sağlamaya ilişkin düşüncelerini ve yaratıcılıklarını ifade etmelerine izin vermek için uygun bir sistem geliştirilebilir. Böylelikle, yaratıcı fikirler ile örgütlerin performansını geliştirmeleri sağlanabilir. Yeni teknolojiler, süreçler, teknikler ya da ürün fikirleri bulmak için işgörenlerin yaratıcılığı örgütsel destek yoluyla teşvik edilebilir ve sorunlara yeni bir yaklaşım getirilebilir.

- Örgüt yönetimlerinin, çalışanların bilgi ve becerilerini arttırmak üzere zaman zaman eğitim programları düzenleyerek onları güçlendirmeleri ve adil bir performans değerlendirmeyle onlara gereken örgütsel desteği sağlamaları yanı sıra, bu araştırmanın da ortaya koyduğu gibi, düzenli aralıklarla hizmet kalitesi üzerinde etkili olan, işgörenlerin örgütsel destek ve güçlendirmeye ilişkin tutumlarını ölçmeleri ve böylelikle hizmet kalitesini sürekli iyileştirerek, işletmenin stratejik planına katkıda bulunmaları önerilir.

Araştırmada işletmelerde, güçlendirme ve örgütsel destek faaliyetlerinin olmasının, hizmet kalitesini artırdığı sonucuna varılması nedeniyle, işletmelerin örgütsel destek ve personel güçlendirmeye bağlı olarak hizmet kalitesini aşağıda belirtilen durumlar çerçevesinde yükseltebilecekleri öne sürülebilir:

- İşgörenler güçlendirilerek kendi başlarına karar verme yetileri arttırıldığında, daha hızlı karar verip aksaklıkların daha çabuk giderilmesi sağlanarak,

- Örgütsel destek ile işgörenlerin işlerini ya da görevlerini tamamlama istekleri ve çabaları arttırilarak,

- Örgütsel destek ve personel güçlendirme ile işgörenlerin motivasyonları, performansları ve işi sahiplenme isteği arttırılarak.

Özet olarak, ağırlama endüstrisindeki işletmelerin hizmet kalitesini yükseltmede,örgütsel destek ve personel güçlendirme faaliyetlerini etkili bir şekilde yürütmeleri ve ayrıca çalışanların örgütsel uygulamalara ilişkin algılarının olumlu olması, kendilerine destek verildiğini düşünmeleri sağlanmalıdır.

\section{KAYNAKÇA}

Al-Ababneh, M. M. (2017). Service Quality in The Hospitality Industry. Journal of Tourism $\mathcal{E}$ Hospitality, 6(1) [Online] https://www.researchgate.net/publication/316881857_Service_Quality_in_the_Hospitality_Indu stry [Erişim Tarihi: 27.11.2017].

Alpar, R. (2017). Uygulamalı çok değşsenli istatistiksel yöntemler. (5.Basım). Ankara:Detay Yatıncılık. 
Baron, R. M. and Kenny, D. A. (1986). The Moderator-Mediator Variable Distinction in Social Psychological Research: Conceptual, Strategic, and Statistical Considerations, Journal of Personality and Social Psychology, 51(6): 1173-1182.

Baumgartner, J. (2014). Benefits of Employee Empowerment for Service Quality and Job Satisfaction in The Hospitality Industry. Degree of Doctor, Modul Vienna University.

Bayram, N. (2009). Sosyal Bilimlerde Spss ile Veri Analizi. İstanbul: Ezgi Kitabevi.

Chandrupatla, T. R. (2009). Quality and Reliability In Engineering. United States of America: Cambridge University Press.

Chiu L. H. and Henry, L.L. (1990). Development and Validation of The Mathematics Anxiety Sacle For Children. Measurement and Evaluation In Counseling and Development, 23(3): 121-127.

Chow, I. H., Lo, T. W., Sha, Z. and Hong, J. (2006). The Impact of Developmental Experience, Empowerment, and Organizational Support on Catering Service Staff Performance. Hospitality Management, 25(3): 478-495.

Dimitriades, Z. S. and Maroudas, T. S. (2007). Demographic Predictors of Service Satisfaction in Greek Public Organizations, Measuring Business Excellence, 11(2): 32-43.

Eisenberger, R., Huntington, R., Hutchison, S. and Sowa, D. (1986). Perceived Organizational Support. Journal of Applied Psycology, 71(3): 500-507.

Ertaş, Ç. ve Unur, K. (2018). Kültürel Değerlerin Örgütsel Adalet Algısına Etkisi: Otel Çalışanları Örneği, Yönetim ve Ekonomi Araştırmaları Dergisi, 16(1): 206-239.

Garg, S. and Dhar, R. L. (2014). Effects of Stress, LMX and Perceived Organizational Support on Service Quality: Mediating Effects of Organizational Commitment, Journal of Hospitality and Tourism Management, 21: 64-75.

Gerstner, C. R. and Day, D. V. (1997). Meta - Analytic Review of Leader Member Exchange Theory: Correlates And Construct Issues.Journal of Applied Psychology, 82(6): 827-844.

Grönroos, C. (2001). Service Management and Marketing: A Customer Relationship Management Approach. (2.Basım), England: John Wiley.

Ivanovic, S. and Blazevic, M. (2009). Human Resource Management in The Hospitality Industry.Tourism and Hospitality Management, 15(1): 107-116.

Kalaycı, Ş. (2014). SPSS Uygulamalı Çok Değişkenli İstatistik Teknikleri. (6.Basım), Ankara:Asil.

Karasar, N. (2014). Bilimsel Araştırma Yöntemi. Ankara: Nobel Akademik Yayıncılık.

Karavardar, G. (2014). Perceived Organizational Support, Psychological Empowerement, Organizational Citizen Behavior, Job Performance and Job Embeddedness: A Research on The Fast Food Industry in İstanbul, Turkey, 9(4): 131-139.

Kaya, Z., Taşdemir, Ş., Akbaşlı, S., Şahin, M., Altın, M., Yağcı, M., Doğan, O., İslam, Y., Kayış, A., Nacar, D., Sayın, N. ve Ünver, M. (2013). Araştırma Yöntemleri ve Teknikleri, (Edit. Zeki Kaya ve Mehmet Şahin), Konya:Eğitim Yayınevi.

Kraimer, M. L. and Wayne, S. J. (2004). An Examination of Perceived Organizational Support As A Multidimensional Construct in The Context of An Expatriate Assignment. Journal of Management, 30(2): 209-237.

Larkin, M. E., Cierpial, C. L., Stack, J. M., Morrison, V. J. and Griffith, C. A. (2008). Empowerment theory in action: the wisdom of collaborative governance. Online Journal Of Issues In Nursing, 13(2) 
[Online] http://web.a.ebscohost.com/ehost/detail/detail?vid=2\&sid=cd6319ec-3f7a-4e7f-9570524f5e3fec52\%40sessionmgr4006\&bdata=Jmxhbmc9dHImc210ZT1laG9zdC1saXZl\#db=a9h\&AN $=37180519$ [Erişim Tarihi: 17.12.2017].

Lord, J. and Hutchison, P. (1993). The process of Empowerment: Implications for Theory and Practice. Canadian Journal of Community Mental Health, 12(1): 5-22.

Malhotra, N. and A. Mukherjee, (2004), .The Relative Influence of Organizational Commitment and Job Satisfaction on Service Quality of Customer Contact Employees in Banking Call Centers. Journal of Services Marketing, 18(3): 162-174.

Munhurrun, P. R.,Naidoo, P. and Bhiwajee, S. D. (2010). Measuring Service Quality: Perceptions of Employees. Global Journal of Business Research, 4(1): 47-58.

Moorman, R. H. (1991). Relationship Between Organizational Justice and Organizational Citizenship Behaviors: Do Fairness Perceptions Influence Employee Citizenship?. Journal of Applied Psychology, 76(6): 845-855.

O'Brien, J. L. (2010). Structural Empowerment, Psychological Empowerment and Burnout in Registered Staff Nurses Working in Outpatient Dialysis Centers. Degree of Doctor, The State University of New Jersey.

Özbek, M. F. ve Kosa G. (2010). Duygusal Bağlllık, Örgütsel Destek, Üst Yönetim Desteği ve Personel Güçlendirmenin Hizmet Kalitesi üzerindeki Etkisi: Kırgızistan'da Banka İşgörenler Üzerinde Bir Uygulama. Erciyes Üniversitesi İktisadi ve İdari Bilimler Fakültesi Dergisi, 34:189-212.

Parasuraman, A.,Zeithaml, V. A. and Berry, L. L. (1985). A Conceptual Model of Service Quality And Its İmplications for Future Research. Journal of Marketing, 49: 41-50.

Parasuraman, A., Zeithaml, V. A. and Berry, L. L. (1988). Serqual: A Multiple-Item Scale for Measuring Consumer Perceptions of Service Quality. Journal of Retailing, 64(1): 12-40.

Ramos, A. O. and Ales, Y. B. (2014). Empowering Employees: Structural Empowerment As Antecedent of Job Satisfaction in University Settings. Psychological Thought, 7(1): 28-36.

Regan, V. J. (1963). The Service Revolation. Journal of Marketing, 27(3): 57-62.

Saltürk, M. (2008). Yönetim Başarısı ve Kişilik. İstanbul: Toplumsal Dönüşüm Yayınları.

Samat, N., Ramayah, T. and Saad, N. M. (2006). TQM Practices, Service Quality, and Market Orientation Some Empirical Evidence From A Developing Country, Management Research News, 29(11): 713-728.

Seng, N. L. and Arumugan, T. (2017). Financial Reward and Motivation Toward Employee Job Performance in The Hospitality Industry in Klang Valley. Electronic Journal of Business $\mathcal{E}$ Management, 2(1): 51-60.

Singh, A. K. and Singh, A. P. (2010). Role of Stress and Organizational Support in Predicting Organizational Citizenship Behavior. The IUP Journal of Organizational Behavior, 9(4): 7-25.

Spreitzer, G.M. (1995). Psychological Empowerment in The Workplace: Dimensions, Measurement, Andvalidation. The Academy of Management Journal, 38(5): 1442-1465.

Spreitzer, G.M. (1995). Social structure characteristics of psychological empowerement. Academy of Management Journal, 39(2): 483-504.

Ural, A.ve Kılıç, İ. (2006). Bilimsel Araştırma Süreci ve Spss İle Veri Analizi. (2. Basım), Ankara: Detay Yayıncilik. 
Wu, H. C. and Ko,Y. J. (2013). Assessment of Service Quality in The Hotel Industry. Journal of Quality Assurance In Hospitality \& Tourism, 14: 218 - 244.

Zincirkıran, M., Yalçınsoy, A. ve Işık, M. (2016). Yönetici Desteği İle İş Memnuniyeti Arasındaki İlişkinin İncelenmesi. [Online] https://www.researchgate.net/publication/310753516_Yonetici_Destegi_Ile_Is_Memnuniyeti_Ar asindaki_Iliskinin_Incelenmesi [Erişim Tarihi: 30.01.2018]. 
EK-1. Örgütsel Desteğin Etki Boyutu Üzerine Etkisi

\begin{tabular}{|c|c|c|c|c|c|c|c|}
\hline \multicolumn{8}{|c|}{ Katsayılar } \\
\hline \multirow[b]{2}{*}{ Model } & \multicolumn{2}{|c|}{$\begin{array}{c}\text { Standardize } \\
\text { Edilmemiş Katsayılar }\end{array}$} & \multirow{2}{*}{$\begin{array}{c}\begin{array}{c}\text { Standardize } \\
\text { Katsayılar }\end{array} \\
\text { Beta }\end{array}$} & \multirow[b]{2}{*}{$\mathrm{T}$} & \multirow[b]{2}{*}{ Sig. } & \multirow[b]{2}{*}{ Tolerance } & \multirow[b]{2}{*}{ VIF } \\
\hline & $\mathrm{B}$ & Std. Hata & & & & & \\
\hline 1 (Sabit) & 2,122 & 201 & & 10,551 & ,000 & & \\
\hline Önemsenme &, 538 & ,076 & 479 & 7,030 &, 000 & ,387 & 2,584 \\
\hline Göz Ardı Edilme Durumu &, 005 & ,056 & ,005 & ,082 & ,935 &, 533 & 1,878 \\
\hline Gözden Çıkarılma Durumu &,- 026 & 061 &,- 026 &,- 434 & ,665 & 484 & 2,066 \\
\hline Gururlandırma Durumu & 082 & 074 & 071 & 1,104 & 270 & ,438 & 2,285 \\
\hline $\begin{array}{l}\text { Maaşla Ödüllendirme ve } \\
\text { Anlayışla Karşılanma }\end{array}$ &,- 104 & 059 &,- 104 & $-1,756$ & 080 &, 513 & 1,948 \\
\hline
\end{tabular}

EK-2. Örgütsel Desteğin Özerklik ve Yeterlilik Boyutu Üzerine Etkisi

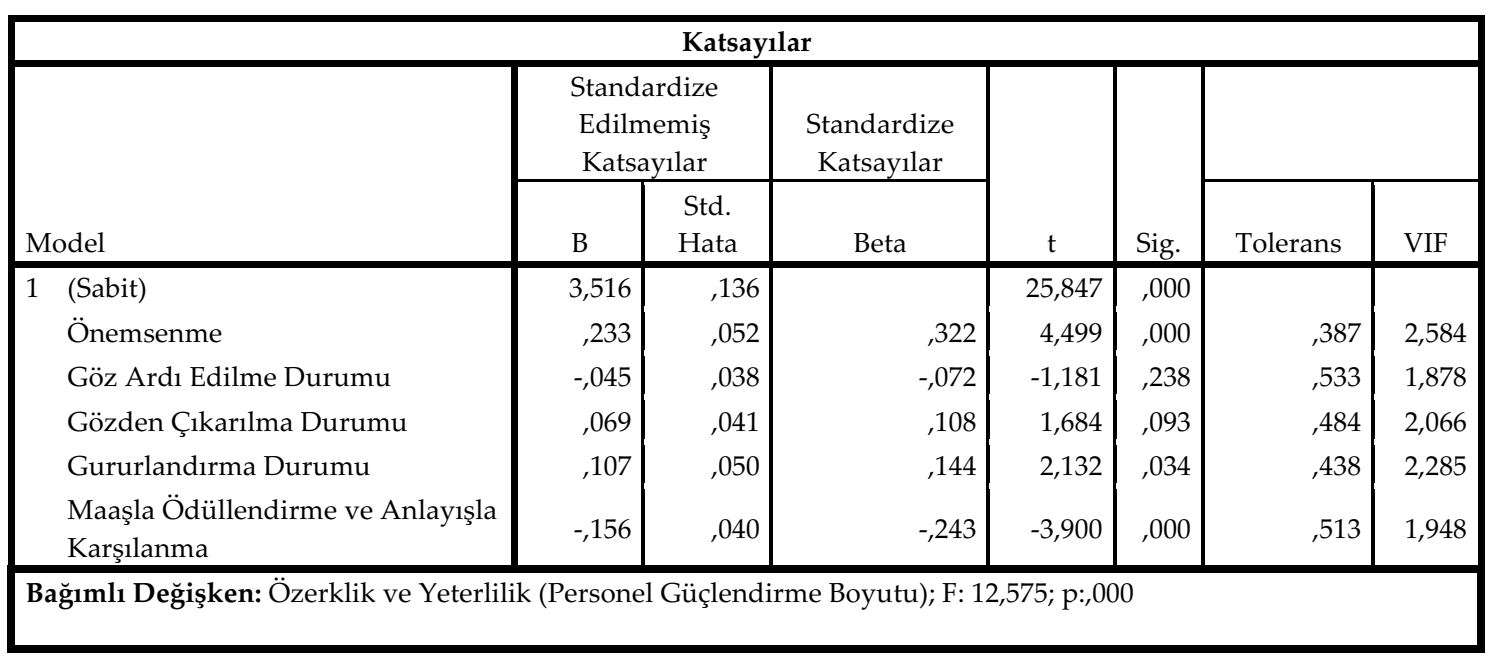

EK-3. Örgütsel Desteğin Anlam Boyutu Üzerine Etkisi

\begin{tabular}{|c|c|c|c|c|c|c|c|}
\hline \multicolumn{8}{|c|}{ Katsayılar } \\
\hline \multirow[b]{2}{*}{ Model } & \multicolumn{2}{|c|}{$\begin{array}{c}\text { Standardize } \\
\text { Edilmemiş } \\
\text { Katsayılar }\end{array}$} & \multirow{2}{*}{$\begin{array}{c}\begin{array}{c}\text { Standardize } \\
\text { Katsayılar }\end{array} \\
\text { Beta }\end{array}$} & \multirow[b]{2}{*}{$\mathrm{t}$} & \multirow[b]{2}{*}{ Sig. } & \multirow[b]{2}{*}{ Tolerans } & \multirow[b]{2}{*}{ VIF } \\
\hline & B & $\begin{array}{l}\text { Std. } \\
\text { Hata }\end{array}$ & & & & & \\
\hline $1 \quad$ (Sabit) & 3,393 & ,151 & & 22,502 & , 000 & & \\
\hline Önemsenme & ,223 & 057 & ,280 & 3,885 &, 000 & ,387 & 2,584 \\
\hline Göz Ardı Edilme Durumu &,- 021 & 042 &,- 031 &,- 505 & 614 &, 533 & 1,878 \\
\hline Gözden Çıkarılma Durumu & , 054 & 046 & ,076 & 1,178 &, 239 & ,484 & 2,066 \\
\hline Gururlandirma & ,051 & 056 & , 062 & ,916 &, 360 & ,438 & 2,285 \\
\hline $\begin{array}{l}\text { Maaşla Ödüllendirme ve Anlayışla } \\
\text { Karşılanma }\end{array}$ &,- 025 & 044 &,- 036 &,- 575 &, 566 &, 513 & 1,948 \\
\hline
\end{tabular}


EK-4. Örgütsel Desteğin Sorumluluk ve Empati Boyutu Üzerine Etkisi

\begin{tabular}{|c|c|c|c|c|c|c|c|}
\hline \multirow[b]{3}{*}{ Model } & \multicolumn{3}{|c|}{ Katsayılar } & \multirow[b]{3}{*}{$\mathrm{t}$} & \multirow[b]{3}{*}{ Sig. } & & \\
\hline & \multicolumn{2}{|c|}{$\begin{array}{c}\text { Standardize } \\
\text { Edilmemiş } \\
\text { Katsayılar }\end{array}$} & \multirow{2}{*}{$\begin{array}{c}\begin{array}{c}\text { Standardize } \\
\text { Katsayilar }\end{array} \\
\text { Beta }\end{array}$} & & & \multirow[b]{2}{*}{ Tolerans } & \multirow[b]{2}{*}{ VIF } \\
\hline & B & $\begin{array}{l}\text { Std. } \\
\text { Hata }\end{array}$ & & & & & \\
\hline 1 (Sabit) & 3,653 & ,121 & & 30,092 &, 000 & & \\
\hline Önemsenme & ,110 & ,046 & 174 & 2,389 & 017 & 387 & 2,584 \\
\hline Göz Ardı Edilme Durumu &,- 003 & ,034 &,- 006 &,- 102 & ,919 &, 533 & 1,878 \\
\hline Gözden Çıkarılma Durumu & ,066 & , 037 & 117 & 1,791 &, 074 & 484 & 2,066 \\
\hline Gururlandirma & ,116 & ,045 & 177 & 2,573 & 010 & ,438 & 2,285 \\
\hline $\begin{array}{l}\text { Maaşla Ödüllendirme ve Anlayışla } \\
\text { Karşılanma }\end{array}$ &,- 112 & ,036 &,- 199 & $-3,134$ & ,002 &, 513 & 1,948 \\
\hline
\end{tabular}

EK-5. Örgütsel Desteğin Güven Verme ve Özen Gösterme Boyutu Üzerine Etkisi

\begin{tabular}{|c|c|c|c|c|c|c|c|}
\hline \multirow[b]{3}{*}{ Model } & \multicolumn{3}{|c|}{ Katsayılar } & \multirow[b]{3}{*}{$t$} & \multirow[b]{3}{*}{ Sig. } & & \\
\hline & \multicolumn{2}{|c|}{$\begin{array}{c}\text { Standardize } \\
\text { Edilmemiş } \\
\text { Katsayıla }\end{array}$} & \multirow{2}{*}{$\begin{array}{c}\text { Standardize } \\
\text { Katsayilar } \\
\text { Beta }\end{array}$} & & & \multirow[b]{2}{*}{ Tolerans } & \multirow[b]{2}{*}{ VIF } \\
\hline & $\mathrm{B}$ & $\begin{array}{l}\text { Std. } \\
\text { Hata }\end{array}$ & & & & & \\
\hline \multirow{6}{*}{$\begin{array}{ll}1 \text { (Sabit) } \\
\text { Önemsenme } \\
\text { Göz Ardı Edilme Durumu } \\
\text { Gözden Çıkarılma Durumu } \\
\text { Gurulandırma } \\
\text { Maaşla Ödüllendirme ve Anlayışla } \\
\text { Karşılanma }\end{array}$} & 3,536 & , 142 & & 24,984 & ,000 & & \\
\hline & 181 & ,054 & ,246 & 3,355 & ,001 & ,387 & 2,584 \\
\hline & ,023 & ,040 & ,036 &, 580 &, 562 & ,533 & 1,878 \\
\hline & ,010 & ,043 & ,015 & ,230 & ,818 & ,484 & 2,066 \\
\hline & ,064 & ,052 & ,084 & 1,223 & ,222 & ,438 & 2,285 \\
\hline &,- 057 & ,042 &,- 088 & $-1,379$ & , 169 & ,513 & 1,948 \\
\hline
\end{tabular}

EK-6. Örgütsel Desteğin Sorumluluk ve Empati Boyutu Üzerindeki Etkisinde Personel Güçlendirmenin Aracılık Etkisi

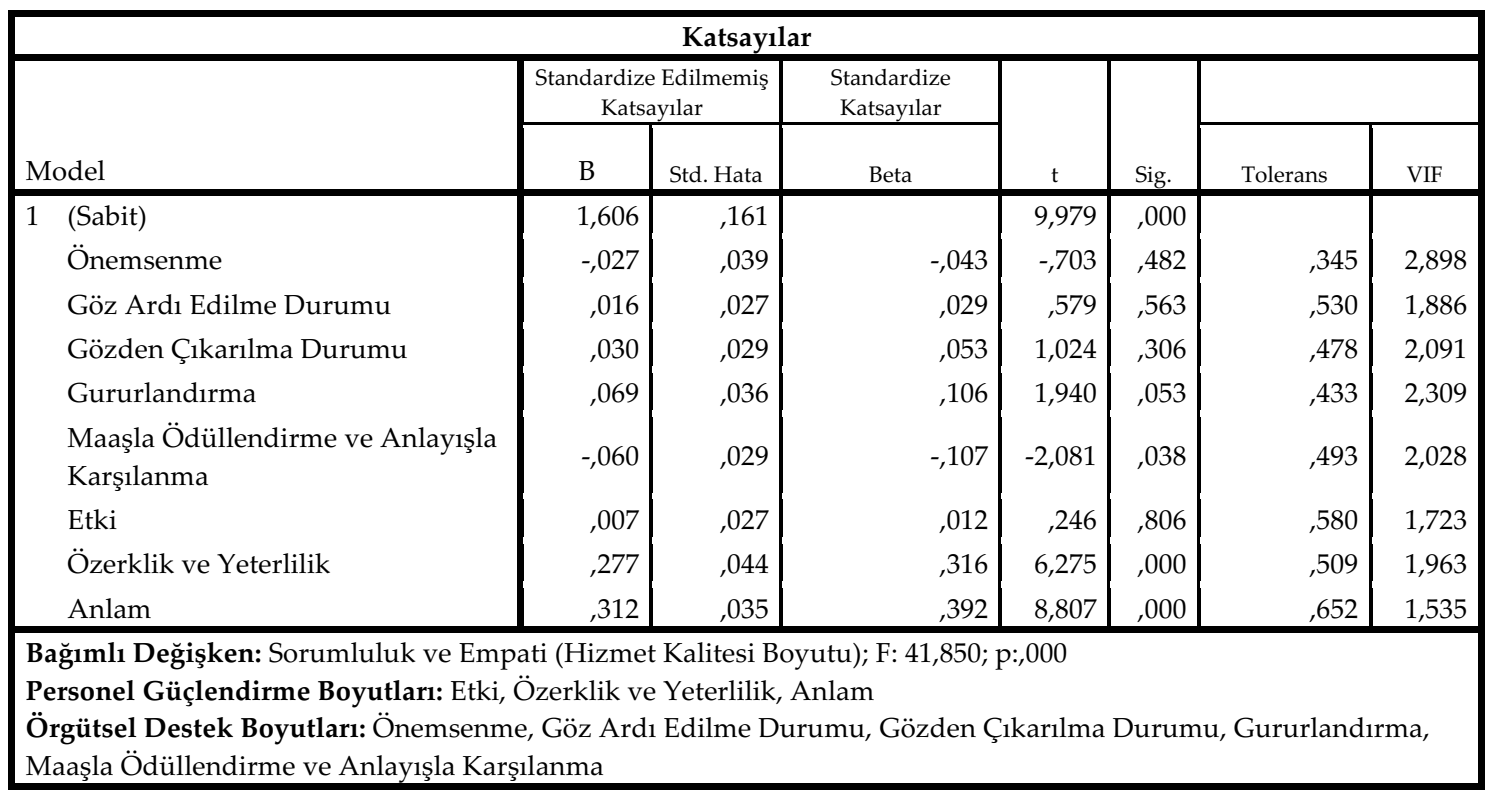


EK-7. Örgütsel Desteğin Güven Verme ve Özen Gösterme Boyutu Üzerindeki Etkisinde Personel Güçlendirmenin Aracılık Etkisi

\begin{tabular}{|c|c|c|c|c|c|c|c|}
\hline \multirow[b]{3}{*}{ Model } & \multicolumn{3}{|c|}{ Katsayılar } & \multirow[b]{3}{*}{$t$} & \multirow[b]{3}{*}{ Sig. } & & \\
\hline & \multicolumn{2}{|c|}{$\begin{array}{l}\text { Standardize } \\
\text { Edilmemiş } \\
\text { Katsayılar }\end{array}$} & \multirow{2}{*}{$\begin{array}{c}\text { Standardize } \\
\text { Katsayılar } \\
\text { Beta }\end{array}$} & & & \multirow[b]{2}{*}{ Tolerans } & \multirow[b]{2}{*}{ VIF } \\
\hline & B & $\begin{array}{l}\text { Std. } \\
\text { Hata }\end{array}$ & & & & & \\
\hline \multirow{9}{*}{$\begin{array}{ll}1 \text { (Sabit) } \\
\text { Önemsenme } \\
\text { Göz Ardı Edilme Durumu } \\
\text { Gözden Çıkarılma Durumu } \\
\text { Gururlandırma } \\
\text { Maaşla Ödüllendirme ve Anlayışla } \\
\text { Karşlanma } \\
\text { Etki } \\
\text { Özerklik ve Yeterlilik } \\
\text { Anlam }\end{array}$} & 1,343 & ,196 & & 6,836 & , 000 & & \\
\hline & , 041 & ,047 & ,055 & 861 & 390 & ,345 & 2,898 \\
\hline & ,044 & ,033 & ,069 & 1,332 & 184 &, 530 & 1,886 \\
\hline &,- 030 & ,036 &,- 045 &,- 831 & ,406 & ,478 & 2,091 \\
\hline & ,015 & ,044 & ,020 & ,351 & ,726 & ,433 & 2,309 \\
\hline &,- 003 & ,035 &,- 005 &,- 088 & ,930 & ,493 & 2,028 \\
\hline &,- 012 & ,032 &,- 018 &,- 365 & 715 &, 580 & 1,723 \\
\hline & ,300 & 054 & ,295 & 5,568 & ,000 &, 509 & 1,963 \\
\hline & 343 & ,043 & ,372 & 7,936 & ,000 & 652 & 1,535 \\
\hline \multicolumn{8}{|c|}{$\begin{array}{l}\text { Bağımlı Değişken: Güven Verme ve Özen Gösterme (Hizmet Kalitesi Boyutu); F: 32,579; p:,000 } \\
\text { Personel Güçlendirme Boyutları: Etki, Özerklik ve Yeterlilik, Anlam } \\
\text { Örgütsel Destek Boyutları: Önemsenme, Göz Ardı Edilme Durumu, Gözden Çıkarılma Durumu, Gururlandırma, } \\
\text { Maaşla Ödüllendirme ve Anlayışla Karşılanma }\end{array}$} \\
\hline
\end{tabular}

EK-8. Sobel Testi'nin Online Hesaplama Programına İlişkin Ekran Görüntüsü

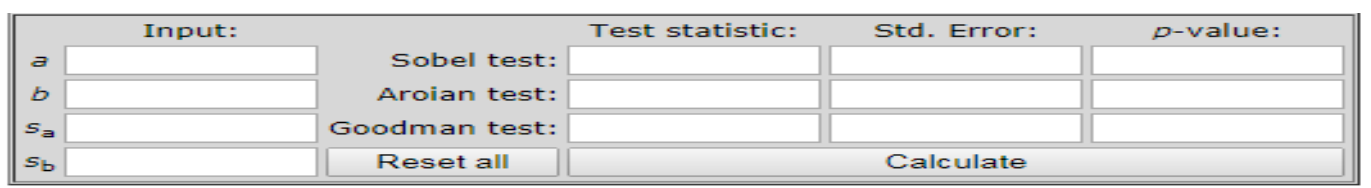

http://quantpsy.org/sobel/sobel.htm, 15.08.2018.

Ek-9: Algılanan Örgütsel Desteğin Hizmet Kalitesine Etkisinde Personel Güçlendirmenin Aracıllk Etkisi

\begin{tabular}{|c|c|c|c|c|c|c|c|c|c|c|c|c|}
\hline \multirow[t]{2}{*}{$\begin{array}{l}\text { Bağımlı } \\
\text { Değişken }\end{array}$} & \multirow{2}{*}{$\begin{array}{c}\text { Model } \\
\text { (Sabit) ve } \\
\text { Bağımsız } \\
\text { Değişken } \\
\text { ve Aracı } \\
\text { Değişken }\end{array}$} & \multicolumn{2}{|c|}{ 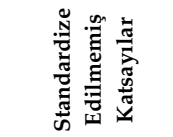 } & \multirow{2}{*}{ 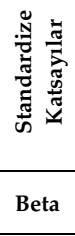 } & \multirow[t]{2}{*}{$\mathrm{T}$} & \multirow{2}{*}{ 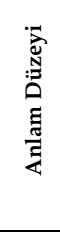 } & \multicolumn{2}{|c|}{ ANOVA } & \multirow{2}{*}{ 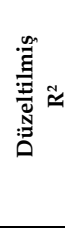 } & \multirow[t]{2}{*}{$\approx$} & \multirow{2}{*}{ 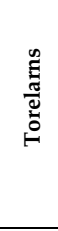 } & \multirow[t]{2}{*}{ V.I.F } \\
\hline & & Beta & $\begin{array}{l}\text { Std. } \\
\text { Hata }\end{array}$ & & & & $\mathbf{F}$ & $\begin{array}{l}\text { Anlam } \\
\text { Düzeyi }\end{array}$ & & & & \\
\hline \multirow{3}{*}{$\begin{array}{c}\text { Sorumluluk } \\
\text { ve Empati }\end{array}$} & Sabit & 3,449 & ,121 & & 28,563 & ,000 & \multirow{3}{*}{32,594} & \multirow{3}{*}{,000 } & \multirow{3}{*}{,124 } & \multirow{3}{*}{, 128 } & & \\
\hline & Önemsenme & ,056 & ,031 & ,089 & 1,792 & ,074 & & & & & ,799 & 1,252 \\
\hline & Etki &, 174 &, 028 &, 309 & 6,232 &, 000 & & & & & ,799 & 1,252 \\
\hline \multirow{3}{*}{$\begin{array}{l}\text { Sorumluluk } \\
\text { ve Empati }\end{array}$} & Sabit & 2,111 & ,159 & & 13,295 & ,000 & \multirow{3}{*}{104,783} & \multirow{3}{*}{,000 } & \multirow{3}{*}{,318 } & \multirow{3}{*}{,321 } & & \\
\hline & Önemsenme & ,045 & ,029 &, 071 & 1,734 & ,084 & & & & & ,916 & 1,091 \\
\hline & $\begin{array}{c}\text { Ozerklik ve } \\
\text { Yeterlilik }\end{array}$ & 474 & ,039 &, 054 & 13,257 & ,000 & & & & & ,916 & 1,091 \\
\hline \multirow{3}{*}{$\begin{array}{c}\text { Sorumluluk } \\
\text { ve Empati }\end{array}$} & Sabit & 2,251 & ,145 & & 15,525 &, 000 & \multirow{3}{*}{114,473} & \multirow{3}{*}{000} & \multirow{3}{*}{,337 } & \multirow{3}{*}{, 340} & & \\
\hline & Önemsenme & ,026 & ,026 &, 042 & 1,019 & ,309 & & & & & ,893 & 1,120 \\
\hline & Anlam &, 452 &, 032 &, 568 & 13,933 &, 000 & & & & &, 893 & 1,120 \\
\hline \multirow{3}{*}{$\begin{array}{c}\text { Güven } \\
\text { Verme ve } \\
\text { Özen } \\
\text { Gösterme }\end{array}$} & Sabit & 3,276 & 140 & & 23,354 & ,000 & \multirow{3}{*}{31,911} & \multirow{3}{*}{,000 } & \multirow{3}{*}{,122 } & \multirow{3}{*}{,126 } & & \\
\hline & Önemsenme & 116 & ,036 & , 158 & 3,175 & ,002 & & & & & ,799 & 1,252 \\
\hline & Etki & ,166 & ,032 & ,255 & 5,128 &, 000 & & & & & ,799 & 1,252 \\
\hline \multirow{3}{*}{$\begin{array}{l}\text { Güven } \\
\text { Verme ve } \\
\text { Özen } \\
\text { Gösterme }\end{array}$} & Sabit & 1,900 & 190 & & 10,009 &, 000 & \multirow{3}{*}{85,828} & & & & & \\
\hline & Önemsenme & ,099 & ,031 & , 135 & 3,210 & ,001 & & ,000 & ,276 & ,279 & ,916 & 1,091 \\
\hline & $\begin{array}{c}\text { Özerklik ve } \\
\text { Yeterlilik }\end{array}$ &, 480 & ,043 & ,473 & 11,232 & ,000 & & & & & ,916 & 1,091 \\
\hline Güven & Sabit & 1,964 & ,171 & & 11,463 &, 000 & 102,440 & 000 &, 313 & 316 & & \\
\hline Verme ve & Önemsenme & ,075 & ,030 & , 102 & 2,446 & ,015 & & & & &, 893 & 1,120 \\
\hline
\end{tabular}




\begin{tabular}{|c|c|c|c|c|c|c|c|c|c|c|c|c|}
\hline $\begin{array}{c}\text { Özen } \\
\text { Gösterme }\end{array}$ & Anlam & ,480 & ,038 & ,520 & 12,527 & 000, & & & & & ,893 & 1,120 \\
\hline \multirow{4}{*}{$\begin{array}{c}\text { Sorumluluk } \\
\text { ve Empati }\end{array}$} & Sabit & 3,454 & 119 & & 29,061 & ,000 & \multirow{4}{*}{32,630} & \multirow{4}{*}{,000 } & \multirow{4}{*}{ 124 } & \multirow{4}{*}{ 128 } & \multirow{4}{*}{$\begin{array}{l}966 \\
9666\end{array}$} & \multirow{4}{*}{$\begin{array}{l}1,035 \\
1,035\end{array}$} \\
\hline & $\begin{array}{l}\text { Göz Ardı } \\
\text { Edilme }\end{array}$ & ,044 & ,025 & 082 & 1,809 & 071 & & & & & & \\
\hline & Durumu & & & & & & & & & & & \\
\hline & $\begin{array}{l}\text { Etki } \\
\text { Sabit }\end{array}$ & $\frac{188}{2077}$ & , 025 & , 334 & $\begin{array}{l}7,406 \\
12974\end{array}$ & $\begin{array}{l}, 000 \\
000\end{array}$ & & & & & & \\
\hline \multirow{3}{*}{$\begin{array}{c}\text { Sorumluluk } \\
\text { ve Empati }\end{array}$} & Göz Ardı & & & & & & \multirow{3}{*}{106,170} & \multirow{3}{*}{,000 } & \multirow{3}{*}{,320 } & \multirow{3}{*}{,324 } & 090 & \multirow{3}{*}{$\begin{array}{l}1,010 \\
1,010\end{array}$} \\
\hline & $\begin{array}{l}\text { Ed1lme } \\
\text { Durumu }\end{array}$ & , & ,021 & ,087 & 2,214 & ,027 & & & & & ,990 & \\
\hline & $\begin{array}{c}\text { Özerklik ve } \\
\text { Yeterlilik }\end{array}$ & 485 & ,034 & ,553 & 14,104 & ,000 & & & & & ,990 & \\
\hline \multirow{3}{*}{$\begin{array}{c}\text { Sorumluluk } \\
\text { ve Empati }\end{array}$} & Sabit & 2,233 & 145 & & 15,403 & ,000 & \multirow{3}{*}{115,155} & \multirow{3}{*}{,000 } & \multirow{3}{*}{,339 } & \multirow{3}{*}{,342 } & & \multirow{3}{*}{$\begin{array}{l}1,024 \\
1,024\end{array}$} \\
\hline & $\begin{array}{l}\text { Edilme } \\
\text { Durumu }\end{array}$ & ,030 & ,021 & ,054 & 1,393 & 164 & & & & & ,976 & \\
\hline & Anlam & ,456 &, 031 &, 574 & 14,715 &, 000 & & & & &, 976 & \\
\hline
\end{tabular}

\begin{tabular}{|c|c|c|c|c|c|c|c|c|c|c|c|c|}
\hline \multirow{2}{*}{$\begin{array}{c}\text { Bağımlı } \\
\text { Değişke } \\
n\end{array}$} & \multirow{2}{*}{$\begin{array}{l}\text { Model (Sabit) ve } \\
\text { Bağımsız } \\
\text { Değişken ve } \\
\text { Aracı Değişken }\end{array}$} & \multicolumn{2}{|c|}{$\begin{array}{l}\text { Standardize } \\
\text { Edilmemiş } \\
\text { Katsayılar }\end{array}$} & \multirow{2}{*}{ 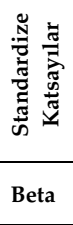 } & \multirow[t]{2}{*}{$t$} & \multirow{2}{*}{ 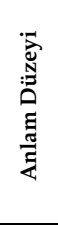 } & \multicolumn{2}{|c|}{ ANOVA } & \multirow[t]{2}{*}{ 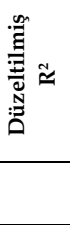 } & \multirow[t]{2}{*}{$\approx$} & \multirow[t]{2}{*}{ 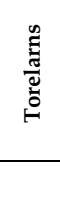 } & \multirow[t]{2}{*}{ V.I.F. } \\
\hline & & Beta & $\begin{array}{l}\text { Std. } \\
\text { Hata }\end{array}$ & & & & $\mathbf{F}$ & $\begin{array}{l}\text { Anlam } \\
\text { Düzeyi }\end{array}$ & & & & \\
\hline \multirow{3}{*}{$\begin{array}{l}\text { Güven } \\
\text { Verme } \\
\text { ve Özen } \\
\text { Gösterm } \\
\text { e }\end{array}$} & Sabit & 3,360 & 139 & & 24,188 & ,000 & \multirow{3}{*}{$\begin{array}{c}28,88 \\
8\end{array}$} & \multirow{3}{*}{,000 } & \multirow{3}{*}{,111 } & \multirow{3}{*}{,115 } & & \multirow{3}{*}{$\begin{array}{l}1,035 \\
1,035\end{array}$} \\
\hline & $\begin{array}{c}\text { Göz Ardı Edilme } \\
\text { Durumu }\end{array}$ & ,062 & ,029 & ,098 & 2,162 & ,031 & & & & & ,966 & \\
\hline & Etki & ,201 & ,030 & ,307 & 6,765 & ,000 & & & & & ,966 & \\
\hline \multirow{3}{*}{$\begin{array}{c}\text { Güven } \\
\text { Verme } \\
\text { ve Özen } \\
\text { Gösterm } \\
\text { e }\end{array}$} & Sabit & 1,923 & ,193 & & 9,986 & ,000 & \multirow{3}{*}{$\begin{array}{c}83,26 \\
5\end{array}$} & \multirow{3}{*}{,000 } & \multirow{3}{*}{,269 } & \multirow{3}{*}{,273 } & & \multirow{3}{*}{$\begin{array}{l}1,010 \\
1,010\end{array}$} \\
\hline & $\begin{array}{l}\text { Göz Ardı Edilme } \\
\text { Durumu }\end{array}$ & ,066 & ,026 & 104 & 2,553 & ,011 & & & & & 990 & \\
\hline & $\begin{array}{c}\text { Özerklik ve } \\
\text { Yeterlilik }\end{array}$ & 509 & ,041 &, 501 & 12,326 & ,000 & & & & & ,990 & \\
\hline \multirow{3}{*}{$\begin{array}{l}\text { Güven } \\
\text { Verme } \\
\text { ve Özen } \\
\text { Gösterm } \\
\text { e }\end{array}$} & Sabit & 2,000 & ,172 & & 11,630 & 000 & \multirow{3}{*}{$\begin{array}{c}100,3 \\
98\end{array}$} & \multirow{3}{*}{,000 } & \multirow{3}{*}{,308 } & & & \\
\hline & $\begin{array}{c}\text { Göz Ardı Edilme } \\
\text { Durumu }\end{array}$ & ,045 & ,025 & 071 & 1,776 & ,076 & & & & ,311 & ,976 & 1,024 \\
\hline & Anlam &, 501 & ,037 &, 543 & 13,615 & ,000 & & & & & ,976 & 1,024 \\
\hline & Sabit & 3,371 & 120 & & 28,144 & 000 & & & & & & \\
\hline $\begin{array}{l}\text { Sorumlu } \\
\text { luk ve } \\
\text { Empati }\end{array}$ & $\begin{array}{l}\text { Gözden } \\
\text { Çıkarılma } \\
\text { Durumu }\end{array}$ & ,077 & ,025 & 137 & 3,030 & ,003 & $\begin{array}{c}35,99 \\
1\end{array}$ & ,000 & 136 & , 140 & ,952 & 1,050 \\
\hline & Etki & 180 & ,025 &, 319 & 7,071 & 000 & & & & & ,952 & 1,050 \\
\hline & Sabit & 2,080 & ,155 & & 13,220 & 000 & & & & & & \\
\hline $\begin{array}{l}\text { Sorumlu } \\
\text { luk ve }\end{array}$ & $\begin{array}{l}\text { Gözden } \\
\text { Çıkarılma } \\
\text { Durumu }\end{array}$ & ,057 & ,022 & 101 & 2,535 & ,012 & $\begin{array}{c}107,2 \\
84\end{array}$ & ,000 & ,323 & ,326 & ,962 & 1,039 \\
\hline & $\begin{array}{l}\text { Özerklik ve } \\
\text { Yeterlilik }\end{array}$ & ,475 & ,035 &, 543 & 13,657 & ,000 & & & & & ,962 & 1,039 \\
\hline Sorumlu & Sabit & 2,205 & ,144 & & 15,347 & ,000 & & & & & & \\
\hline luk ve & Önemsenme & ,047 & ,022 & ,083 & 2,110 & ,035 & $\begin{array}{c}117,0 \\
56\end{array}$ & ,000 & ,342 &, 345 & ,952 & 1,050 \\
\hline Empatı & Anlam & ,448 & ,031 &, 564 & 14,325 &, 000 & & & & & ,952 & 1,050 \\
\hline Güven & Sabit & 3,339 & 141 & & 23,716 & ,000 & & & & & & \\
\hline $\begin{array}{l}\text { Verme } \\
\text { ve Özen } \\
\text { Gösterm }\end{array}$ & $\begin{array}{l}\text { Gözden } \\
\text { Çıkarılma } \\
\text { Durumu }\end{array}$ & ,070 & ,030 & 107 & 2,336 & ,020 & $\begin{array}{c}29,32 \\
5\end{array}$ & ,000 & ,113 & ,117 & ,952 & 1,050 \\
\hline $\mathrm{e}$ & Etki & ,197 & 030 &, 302 & 6,606 & ,000 & & & & & ,952 & 1,050 \\
\hline & Sabit & 1,987 & 190 & & 10,445 & ,000 & & & & & & \\
\hline $\begin{array}{l}\text { Güven } \\
\text { Verme } \\
\text { ve Özen }\end{array}$ & $\begin{array}{l}\text { Gözden } \\
\text { Çıkarılma } \\
\text { Durumu }\end{array}$ & ,050 & ,027 & ,076 & 1,834 &, 067 & $\begin{array}{c}81,12 \\
6\end{array}$ & ,000 & ,264 & ,268 & ,962 & 1,039 \\
\hline $\begin{array}{c}\text { Gösterm } \\
\text { e }\end{array}$ & $\begin{array}{l}\text { Özerklik ve } \\
\text { Yeterlilik }\end{array}$ & ,505 & ,042 & ,497 & 12,006 & ,000 & & & & & ,962 & 1,039 \\
\hline Güven & Sabit & 2,096 & ,171 & & 11,853 & ,000 & & & & & & \\
\hline $\begin{array}{l}\text { Verme } \\
\text { ve Özen }\end{array}$ & $\begin{array}{l}\text { Gözden } \\
\text { Çıkarılma }\end{array}$ & ,035 & ,026 & ,054 & 1,342 & , 180 & 99,42 & ,000 & ,306 & ,309 & ,952 & 1,050 \\
\hline Gösterm & Durumu & & & & & & & & & & & \\
\hline $\mathrm{e}$ & Anlam &, 500 & ,037 &, 542 & 13,403 &, 000 & & & & & ,952 & 1,050 \\
\hline & Sabit & 3,342 & ,127 & & 26,396 & ,000 & & & & & & \\
\hline
\end{tabular}




\begin{tabular}{|c|c|c|c|c|c|c|c|c|c|c|c|c|}
\hline $\begin{array}{c}\text { Sorumlu } \\
\text { luk ve } \\
\text { Empati }\end{array}$ & $\begin{array}{c}\text { Gururlandırma } \\
\text { Etki }\end{array}$ & $\begin{array}{r}, 090 \\
, 170 \\
\end{array}$ & $\begin{array}{l}, 031 \\
, 026 \\
\end{array}$ & $\begin{array}{l}, 137 \\
, 302 \\
\end{array}$ & $\begin{array}{l}2,930 \\
6,457 \\
\end{array}$ & $\begin{array}{l}, 004 \\
, 000 \\
\end{array}$ & $\begin{array}{c}35,66 \\
5\end{array}$ &, 000 & 134 & 138 & $\begin{array}{r}, 885 \\
, 885 \\
\end{array}$ & $\begin{array}{l}1,130 \\
1,130 \\
\end{array}$ \\
\hline \multirow{3}{*}{$\begin{array}{c}\text { Sorumlu } \\
\text { luk ve } \\
\text { Empati }\end{array}$} & Sabit & 2,047 & , 161 & & 12,726 & ,000 & \multirow{3}{*}{$\begin{array}{c}107,5 \\
98\end{array}$} & \multirow{3}{*}{, 000} & \multirow{3}{*}{323} & \multirow{3}{*}{,326 } & & \\
\hline & Gururlandırma & ,069 & 026 & 105 & 2,619 & ,009 & & & & & ,937 & 1,067 \\
\hline & $\begin{array}{c}\text { Özerklik ve } \\
\text { Yeterlilik }\end{array}$ & ,469 & ,035 &, 536 & 13,316 & 000 & & & & & ,937 & 1,067 \\
\hline \multirow{3}{*}{$\begin{array}{c}\text { Sorumlu } \\
\text { luk ve } \\
\text { Empati }\end{array}$} & Sabit & 2,167 & , 148 & & 14,633 & ,000 & \multirow{3}{*}{$\begin{array}{c}117,7 \\
01\end{array}$} & \multirow{3}{*}{, 000} & \multirow{3}{*}{, 344} & \multirow{3}{*}{,346 } & & \multirow{3}{*}{$\begin{array}{l}1,076 \\
1,076 \\
\end{array}$} \\
\hline & Gururlandırma &, 060 & ,026 & ,092 & 2,304 & ,022 & & & & & ,930 & \\
\hline & Anlam &, 444 & ,032 &, 558 & 14,013 &, 000 & & & & &, 930 & \\
\hline
\end{tabular}

\section{Ek-9: (Devami)}

\begin{tabular}{|c|c|c|c|c|c|c|c|c|c|c|c|c|}
\hline \multirow[t]{2}{*}{$\begin{array}{l}\text { Bağımlı } \\
\text { Değişken }\end{array}$} & \multirow{2}{*}{$\begin{array}{l}\text { Model (Sabit) } \\
\text { ve Bağımsız } \\
\text { Değişken ve } \\
\text { Aracı Değişken }\end{array}$} & \multicolumn{2}{|c|}{ 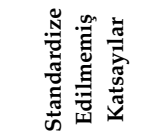 } & \multirow{2}{*}{ 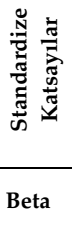 } & \multirow[t]{2}{*}{$t$} & \multirow{2}{*}{ 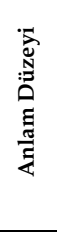 } & \multicolumn{2}{|c|}{ ANOVA } & \multirow{2}{*}{ 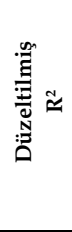 } & \multirow[t]{2}{*}{$\approx$} & \multirow[t]{2}{*}{ 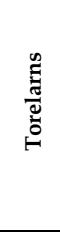 } & \multirow[t]{2}{*}{ V.I.F. } \\
\hline & & Beta & $\begin{array}{l}\text { Std. } \\
\text { Hata }\end{array}$ & & & & F & $\varangle \bar{z}$ & & & & \\
\hline Güven & Sabit & 3,255 & , 148 & & 21,962 & ,000 & & & & & & \\
\hline $\begin{array}{l}\text { Verme ve } \\
\text { Özen } \\
\text { Gösterme }\end{array}$ & $\begin{array}{c}\text { Gururlandırma } \\
\text { Etki }\end{array}$ & $\begin{array}{l}104 \\
, 182 \\
\end{array}$ & $\begin{array}{l}, 036 \\
, 031 \\
\end{array}$ & $\begin{array}{l}138 \\
, 279 \\
\end{array}$ & $\begin{array}{l}2,914 \\
5,897 \\
\end{array}$ & $\begin{array}{l}004 \\
, 000\end{array}$ & 31,023 & ,000 & ,119 & 123 & $\begin{array}{l}, 885 \\
, 885\end{array}$ & $\begin{array}{l}1,130 \\
1,130\end{array}$ \\
\hline $\begin{array}{c}\text { Güven } \\
\text { Verme ve } \\
\text { Özen } \\
\text { Gösterme } \\
\end{array}$ & $\begin{array}{c}\text { Sabit } \\
\text { Gururlandırma } \\
\text { Özerklik ve } \\
\text { Yeterlilik } \\
\end{array}$ & $\begin{array}{c}1,907 \\
, 084 \\
, 492\end{array}$ & $\begin{array}{l}, 194 \\
, 032 \\
\\
, 042\end{array}$ & $\begin{array}{l}111 \\
484\end{array}$ & $\begin{array}{l}9,837 \\
2,650 \\
11,588\end{array}$ & $\begin{array}{l}, 000 \\
, 008 \\
000\end{array}$ & 83,606 & ,000 & ,270 & ,274 & $\begin{array}{l}\text {,937 } \\
\text {,937 }\end{array}$ & $\begin{array}{l}1,067 \\
1,067\end{array}$ \\
\hline $\begin{array}{c}\text { Güven } \\
\text { Verme ve } \\
\text { Özen } \\
\text { Gösterme }\end{array}$ & $\begin{array}{c}\text { Sabit } \\
\text { Gururlandırma } \\
\text { Anlam }\end{array}$ & $\begin{array}{c}1,947 \\
, 070 \\
, 489\end{array}$ & $\begin{array}{l}, 176 \\
, 031 \\
, 038\end{array}$ & $\begin{array}{l}, 092 \\
, 529\end{array}$ & $\begin{array}{c}11,064 \\
2,248 \\
12,986\end{array}$ & $\begin{array}{l}, 000 \\
, 025 \\
, 000\end{array}$ & 101,768 & ,000 & ,311 & ,314 & $\begin{array}{l}930 \\
, 930\end{array}$ & $\begin{array}{l}1,076 \\
1,076\end{array}$ \\
\hline $\begin{array}{l}\text { Sorumluluk } \\
\text { ve Empati }\end{array}$ & $\begin{array}{c}\text { Sabit } \\
\text { Maaşla } \\
\text { Ödüllendirme } \\
\text { ve Anlayışla } \\
\text { Karşllanma } \\
\text { Etki }\end{array}$ & $\begin{array}{r}3,581 \\
-, 008 \\
\\
, 198\end{array}$ & $\begin{array}{l}, 115 \\
, 026 \\
, 026\end{array}$ & $\begin{array}{r}-, 014 \\
, 352\end{array}$ & $\begin{array}{r}31,089 \\
-, 309 \\
7,679 \\
\end{array}$ & $\begin{array}{l}, 757 \\
, 000\end{array}$ & 30,820 & ,000 & ,118 & ,122 & ,939 & $\begin{array}{l}1,065 \\
1,065\end{array}$ \\
\hline $\begin{array}{c}\text { Sorumluluk } \\
\text { ve Empati }\end{array}$ & $\begin{array}{c}\text { Sabit } \\
\text { Maaşla } \\
\text { Ödüllendirme } \\
\text { ve Anlayışla } \\
\text { Karşlanma } \\
\text { Özerklik ve } \\
\text { Yeterlilik }\end{array}$ & $\begin{array}{l}2,153 \\
, 017 \\
\\
, 490\end{array}$ & $\begin{array}{l}, 161 \\
022 \\
, 034\end{array}$ &, 560 & $\begin{array}{r}13,342 \\
1,786 \\
\\
14,235\end{array}$ & $\begin{array}{l}, 432 \\
, 000\end{array}$ & 103,036 & ,000 & ,314 &, 317 & $\begin{array}{l}, 994 \\
\\
, 994\end{array}$ & $\begin{array}{l}1,006 \\
1,006\end{array}$ \\
\hline $\begin{array}{c}\text { Sorumluluk } \\
\text { ve Empati }\end{array}$ & $\begin{array}{c}\text { Sabit } \\
\text { Maaşla } \\
\text { Ödüllendirme } \\
\text { ve Anlayışla } \\
\text { Karşlanma } \\
\text { Anlam }\end{array}$ & $\begin{array}{l}-, 028 \\
, 471\end{array}$ & $\begin{array}{l}, 022 \\
, 031\end{array}$ & $\begin{array}{l}-, 051 \\
, 592\end{array}$ & $\begin{array}{l}-1,282 \\
15,044\end{array}$ & $\begin{array}{l}, 200 \\
, 000\end{array}$ & 114,932 & ,000 & ,338 &, 341 & ,957 & $\begin{array}{l}1,045 \\
1,045\end{array}$ \\
\hline $\begin{array}{l}\text { Güven } \\
\text { Verme ve } \\
\text { Özen } \\
\text { Gösterme }\end{array}$ & $\begin{array}{c}\text { Sabit } \\
\text { Maaşla } \\
\text { Ödüllendirme } \\
\text { ve Anlayışla } \\
\text { Karşlanma } \\
\text { Etki }\end{array}$ & 3,417 & ,134 & ,073 & $\begin{array}{l}1,575 \\
6,657\end{array}$ & $\begin{array}{l}, 116 \\
, 000\end{array}$ & 27,663 & ,000 & ,107 & 111 & $\begin{array}{l}, 939 \\
, 939\end{array}$ & $\begin{array}{l}1,065 \\
1,065\end{array}$ \\
\hline $\begin{array}{l}\text { Güven } \\
\text { Verme ve } \\
\text { Özen } \\
\text { Gösterme }\end{array}$ & $\begin{array}{c}\text { Sabit } \\
\text { Maaşla } \\
\text { Ödüllendirme } \\
\text { ve Anlayışla } \\
\text { Karşlanma } \\
\text { Özerklik ve } \\
\text { Yeterlilik }\end{array}$ & 1,906 & 193 & ,504 & $\begin{array}{l}2,737 \\
12,424\end{array}$ & $\begin{array}{l}, 009 \\
, 000\end{array}$ & 83,923 & ,000 & ,271 & 274 & $\begin{array}{l}, 994 \\
, 994\end{array}$ & $\begin{array}{l}1,006 \\
1,006\end{array}$ \\
\hline $\begin{array}{l}\text { Güven } \\
\text { Verme ve } \\
\text { Özen } \\
\text { Gösterme }\end{array}$ & $\begin{array}{c}\text { Sabit } \\
\text { Maaşla } \\
\text { Ödüllendirme } \\
\text { ve Anlayışla } \\
\text { Karşlanma } \\
\text { Anlam }\end{array}$ & $\begin{array}{l}, 023 \\
, 504\end{array}$ & ,026 & ,035 & $\begin{array}{r}, 865 \\
13,535\end{array}$ & $\begin{array}{l}, 387 \\
, 000\end{array}$ & 98,665 & ,000 & ,305 & ,308 & ,957 & $\begin{array}{l}1,045 \\
1,045\end{array}$ \\
\hline
\end{tabular}

